\title{
HOW THE HEALTH CARE REVOLUTION FELL SHORT
}

\author{
Clark C. HAVIGHURST*
}

\section{INTRODUCTION}

Although they appeared to slow the rate of health care cost increases in the $1990 \mathrm{~s},{ }^{1}$ the health plans that emerged in the marketplace in the managed care era generally disappointed early supporters of the health care revolution. ${ }^{2}$ Most of those reformers envisioned a future in which health maintenance organizations ("HMOs") and other hoped-for organizational innovations would prove to be effective and desirable vehicles for generally improving the quality of care and rationalizing health care spending. A few theorists, however, took a somewhat broader view, and hoped to see the entire health care system transformed into a relatively unfettered competitive market in which spending would reflect primarily the preferences of consumers, not the system's own imperatives. ${ }^{3}$ Reformers of the latter, more market-oriented kind were doomed

Copyright (C) 2002 by Clark C. Havighurst

This article is also available at http://www.law.duke.edu/journals/65LCPHavighurst.

* Professor of Law and William Neal Reynolds Professor of Law (Emeritus), Duke University.

1. Clark C. Havighurst, Is the Health Care Revolution Finished?-A Foreword, 65 LAW \& CONTEMP. PROBS. 1, 2 (Autumn 2002) (discussing cost trends during the era of managed care).

2. Gail Agrawal \& Howard Veit, Back to the Future: The Managed Care Revolution, 65 LAW \& CONTEMP. PROBS. 11, 41 (Autumn 2002) ("The managed care industry ... established its future separate from the goals of early HMO pioneers and the vision of Paul Ellwood and other delivery system reform advocates."). For a discussion of the appropriateness of characterizing the last generation of American health policy as revolutionary, see Havighurst, supra note 1.

3. The crucial difference between these more market-oriented reformers and early advocates of organizational reform was the former's lesser emphasis on reorganization as an end in itself and heavier emphasis on creating a market process that would push industry actors toward efficient organization of medical care and efficient levels of health care spending. For early articles expressing the market reformers' vision, see James F. Blumstein \& Michael Zubkoff, Perspectives on Government Policy in the Health Sector, 51 MILBANK Q. 395 (1973) (discussing the rationale for government intervention in the health sector, health care as a "merit good," and competition as a policy strategy); James F. Blumstein \& Frank A. Sloan, Redefining Government's Role in Health Care: Is a Dose of Competition What the Doctor Should Order?, 34 VAND. L. REV. 849 (1981) (describing and analyzing the market-oriented approach and distinguishing among market advocates); Clark C. Havighurst \& James F. Blumstein, Coping with Quality/Cost Trade-offs in Medical Care: The Role of PSROs, 70 Nw. U.L. REV. 6, 65 (1975) [hereinafter Havighurst \& Blumstein, Coping] (questioning regulatory approach to cost-containment and predicting, "[i]f the health insurance market could be reconstituted to give consumers a range of appropriate choices, some cost-conscious consumers would prefer lower-priced plans which provide fewer and/or lower-quality services"); Clark C. Havighurst, Health Maintenance Organizations and the Market for Health Services, 35 LAW \& CONTEMP. ProBs. 716 (Autumn 1970); Clark C. Havighurst et al., Strategies in Underwriting the Costs of Catastrophic Disease, 40 LAW \& CONTEMP. PROBS. 122, 188 (Autumn 1976) (questioning proposals for comprehensive national health plans on 
to face greater disappointment as the health care industry evolved. This article seeks to explain the failure of the health care revolution to achieve its most ambitious goals, especially the more radical one of installing a truly democratic regime based on competition and real consumer choice. ${ }^{4}$

Early reformers advocating principally organizational reform envisioned health plans that would closely integrate the financing and delivery of care and organize providers into discrete prepaid groups, each striving to compete not just on price but, more importantly, by improving efficiency and the quality of care. ${ }^{5}$ Their hopes for such integration were based in part on observing a few

ground that "political processes dominated by the medical profession and the lifesaving imperative are poorly adapted to making choices with potentially tragic consequences"); Paul Starr, A National Health Program: Organizing Diversity, HASTINGS CENTER REP., Feb. 1975, at 11, 13 (envisioning a system that, "[r]ather than insisting on a uniform definition of the limits of health care, ... encourage[s] a varied set of programs in a community" and "preserves free choice and accommodates cultural diversity"); see also Alain C. ENTHOVEn, THEORY AND PRACTICE OF MANAGED COMPETITION IN HEALTH CARE FINANCE 9-10 (1988) (outlining a structured model of "managed" competition based on the principle that "cost-conscious consumer choice is necessary to create incentives for people to develop and demonstrate less costly alternative ways of organizing medical care of acceptable quality"); CLARK C. Havighurst, Health Care Choices: Private Contracts as Instruments of Health REFORM (1995) [hereinafter HAVIGHURST, HEALTH CARE CHOICES] (arguing that private contracts, rather than regulatory and legal standards, can and should govern patient entitlements and provider and health plan obligations); Einer Elhauge, Allocating Health Care Morally, 82 CAL. L. REV. 1449, 1456 (1994) (outlining health system with voucher-like, risk-adjusted government contributions to competing health plans, "allowing individuals to sign up with the care-allocating plan that offers the health maximization policy they most prefer"); Arti K. Rai, Rationing Through Choice: A New Approach to Cost-Effectiveness Analysis in Health Care, 72 IND. L.J. 1015, 1018 (1997) ("Choice is desirable for the following reasons: first, moral theory does not provide a determinate answer to the question of how we should ration care; second, the most commonly prescribed alternative to moral theory - the democratic political process - does not respect the diversity of individual health and allocational preferences...; and third, choice can be implemented in a manner that not only respects individual autonomy but also attends to other important moral principles, such as justice and beneficence.").

Inevitably, the analysts cited above differ among themselves on important issues. (For example, Enthoven has endorsed substantial standardization of health coverage to facilitate price comparisons, ENTHOVEN, supra, at 104-05, whereas my book envisions product differentiation allowing consumers to choose between explicitly different levels of quality, especially with respect to generosity in covering services of only arguable net benefit in a cost/benefit comparison.) The common threads through all, however, are heavy reliance on competition and cost-conscious consumer choice and acceptance of some measure of inequality, though with substantial public subsidies to ensure a decent minimum level of care for all. See id. at 8 ("I believe in the 'decent minimum' principle of equity, but I do not believe that justice demands that everybody have exactly the same system and style of care."); see also PRESIDENT'S COMMISSION FOR THE STUDY OF ETHICAL PROBLEMS IN MEDICINE AND BIOMEDICAL ANd Behavioral Research, SeCuring ACCESS to Health CARE: The ETHiCAl Implications OF Differences in the AVAilability of HeAlth SERVICEs (1983) (declaring ethical appropriateness of some inequality as long as a decent minimum level of care is socially guaranteed).

4. Because it would dethrone established interests, empower consumers, and subvert conventional wisdom, serious market reform would be radical indeed. Cf. James C. Robinson, Taking Consumers' Rights Seriously, HeAlth AfF., Fall 1996, at 277, 277 (reviewing Havighurst, HeAlth CARE CHOICES, supra note 3) (describing it as "rag[ing] ... through the Augean stables of health policy discourse, filled as they are with intellectual leavings of medical, legal, and bureaucratic elites that for decades have denied consumers their rights under the pretense of promoting those rights and enfeebled the citizenry under the pretense of protecting it").

5. See Agrawal \& Veit, supra note 2, at 20-25; Robert A. Berenson, Beyond Competition, HEALTH AFF., Mar.-Apr. 1997, at 171, 171 (noting that "[t]he logic of managed competition suggests 
highly successful early models of prepaid health care, particularly the Kaiser Foundation Health Plan, Inc. ${ }^{6}$ Unfortunately, modern health plans do not replicate those early, highly integrated models. Even the Kaiser system, while it continued to perform very well relative to other arrangements in the managed care era, encountered difficulty in creating fully integrated organizations in new areas. Likewise, few new health plans, whether start-ups, evolving group medical practices, or innovating health insurers, succeeded in integrating financing, physicians, and capital resources to the same extent that Kaiser did at an early date. Indeed, Kaiser remains virtually unique, in its few core markets, as a stable and effective partnership combining a nonprofit health plan, a nonprofit hospital system, and a fully integrated multi-specialty medical group dedicated solely to caring for a single plan's enrollees.

Market theorists, who hoped to see health care viewed and treated more like a consumer good, have had even more reason to be discouraged by the outcome of the health care revolution. Among other things, the market reform strategy contemplated that consumers, if offered opportunities to choose effective health plan agents for purchasing services and organizing care, would, for the first time, be given choices with different price tags reflecting different trade-offs between quality and cost. ${ }^{8}$ Like the organizational reformers, market reformers envisioned the domestication of providers in integrated

that within each health care market, networks with different and distinct organizational characteristics and internal cultures will form and compete" but that "[h]ealth care markets have not evolved that way").

6. See generally JAmes C. Robinson, The Corporate Practice of Medicine: Competition AND InNOVAtion In HeAlth CARe 74-75 (1999); Jerry Phelan et al., Group Practice Prepayment: An Approach to Delivering Organized Health Services, 35 LAW \& CONTEMP. ProBS. 796 (Autumn 1970) (describing Kaiser's foundational principles).

7. See generally Jeff C. Goldsmith, Integrating Care: A Talk with Kaiser-Permanente's David Lawrence, HEALTH AFF., Jan.-Feb. 2002 at 39. For a discussion of the possibility that Kaiser's performance is superior to that of other HMOs, see Joseph Gottfried \& Frank A. Sloan, The Quality of Managed Care: Evidence from the Medical Literature, 65 LAW \& CONTEMP. PROBS. 103, 113 (Autumn 2002). The managed care revolution saw a number of nonprofit HMOs develop early, only to be converted to for-profit status by managements seeking to capitalize on investors' interest in HMOs. Ironically, today's consumers, who have come to distrust HMOs, see infra Part V, might have greater confidence in plans of the nonprofit variety. Cf. Henry B. Hansmann, Reforming Nonprofit Corporation Law, 129 U. PA. L. REV. 497, 501-11 (1981) (explaining value of nonprofit firms' "nondistribution constraint" to "patrons" unable to evaluate the specific services such firms deliver). Yet tax authorities have made it difficult for nonprofit HMOs to gain tax-exempt status, cutting off sources of needed capital. See, e.g., Geisinger Health Plan v. Comm'r, 985 F.2d 1210 (3d Cir. 1993); IHC Health Plans, Inc. v. Comm'r, 82 T.C.M. (CCH) 593 (2001).

8. On the trade-offs in medical care, see Havighurst \& Blumstein, Coping, supra note 3, at 12-20 (presenting graphic conceptualization of the "quality/cost no man's land," in which no one wants to engage the enemy but in which the battle for efficiency must be fought). Welfare economics teaches us, of course, that trade-offs matter generally in the economy, that quality is not an absolute goal, and that cost-benefit analysis is justified. C $f$. United States v. Carroll Towing Co., 159 F.2d 169, 173 (2d Cir. 1947) (setting forth the famous "Learned Hand" test for negligence, which compares the cost of the potential harm, discounted by its probability, with the cost of preventing its occurrence). Today's health plans, however, have generally not gone so far as to embrace cost-benefit analysis, focusing their cost-containment efforts instead only on "cost effectiveness" and the elimination of services and incremental costs that seem to yield no marginal benefit at all. See generally HAVIGHURST, HEALTH CARE CHOICES, supra note 3, at 92-153. 
organizations. However, they also hoped that competition would cause health plans to cater to differing consumer preferences, seeking in particular to give good value for whatever various subsets of consumers might choose to spend on health coverage. Obviously, the market reformers' vision has also not been realized-even though the health care industry has been functioning under an ostensibly competitive regime for many years and has featured numerous firms offering competing versions of managed health care.

This article begins by noting in Part II the gains made during the revolutionary years of health care reform. The next three Parts then consider seriatim why the health care system failed to reach three specific objectives envisioned by reformers: (1) organizational integration of the delivery of health care with its financing; (2) market responsiveness to a full range of consumer preferences; and (3) the creation of middlemen whom consumers could trust as their agents for administering coverage and protecting premium pools against moral hazard. ' In Part VI of the article, I observe some complexities in both the private market for health coverage and the political market for regulatory and other policies that help to explain the main shortfalls of the health care revolution and the strength of the counter-revolution against managed care. ${ }^{10}$ My special concern is the fate of early hopes for a market regime in which decisions would be driven principally by the preferences of cost-conscious, appropriately subsidized consumers. ${ }^{11}$ After bluntly characterizing American health care today as a regime designed principally by and for its elite consumers and providers at the expense of lower- and middle-income premium payers, I conclude with a few speculations about what may happen next.

\section{II}

\section{GROUND GAINED}

Despite the disappointments of would-be reformers, the health care revolution has generated some very significant gains on behalf of consumers that are unlikely to be lost entirely in the current counter-revolution. Most importantly for the empowerment of consumers, major players in the health care industry, including the organized medical profession, have been clearly

9. "Moral hazard" is the term economists use to capture the distortion in spending decisions that occurs when decision-makers are spending or risking funds other than their own. For the argument that moral hazard associated with health coverage, although it generates additional spending, would not be inefficient in welfare terms if health plans were free to counteract its influence, see infra text accompanying note 84 .

10. On the public backlash against managed care, see generally Clark C. Havighurst, The Backlash Against Managed Health Care: Hard Politics Make Bad Policy, 34 IND. L. REV. 395 (2001) [hereinafter Havighurst, Backlash]; David A. Hyman, Regulating Managed Care: What's Wrong with a Patient Bill of Rights?, 73 S. CAL. L. REV. 221 (2000); Symposium, The Managed Care Backlash, 24 J. HEALTH POL. POL'Y \& L. 873 (1999). See also Havighurst, supra note 1 (discussing the validity of characterizing health care's recent history as one of revolution and counter-revolution).

11. For an expression of early hopes for a truly democratic health care revolution, see Clark C. Havighurst, The Changing Locus of Decision Making in the Health Care Sector, 11 J. HEALTH POL. POL'Y \& L. 697 (1986). 
subject to the antitrust laws since 1975 and have modified their behavior accordingly, no longer acting collectively to restrict the ways in which consumers can purchase health services. ${ }^{12}$ Together with legislation clarifying that health insurers may engage in selective contracting with providers, ${ }^{13}$ early antitrust enforcement enabled health plans for the first time to act as purchasing agents for their subscribers, awarding their principals' business to providers who agreed to charge acceptable prices and to cooperate with the plan in other ways. ${ }^{14}$ Managed care plans have achieved most of their cost savings by extracting competitive price discounts from subcontracting providers rather than by efficiently managing the delivery of care (as HMO supporters envisioned). ${ }^{15}$ Unfortunately, even though the antitrust regime remains in place de jure as a permanent accomplishment of the health care revolution, ${ }^{16}$ it has not

12. The watershed event was Goldfarb v. Va. State Bar, 421 U.S. 773 (1975) (clarifying that the Sherman Act applies to the so-called "learned professions," including medicine). See generally Clark C. Havighurst, Health Care as a (Big) Business: The Antitrust Response, 26 J. HEALTH POL. POL'Y \& L. 939, 942 (2001) ("Few things could have had as revolutionary an effect on the health care sector as the abrupt overturning of the deep-seated policy of trusting medical interests to make and enforce industry rules and set standards for the health care field."). Goldfarb had a profound effect not only on the health care marketplace but also on the substance and direction of national health policy. "After it, policy-makers could and did begin to look to market forces [instead of public regulation] to allocate resources and guide the industry's development." Id. at 942-43.

13. So-called preferred-provider arrangements got a surprising lift in 1982, when the California legislature not only provided for selective contracting with hospitals under Medicaid but also enacted unheralded amendments expressly allowing private insurers to engage in similar selectivity toward providers of all kinds. CAL. WELF. INST. CODE $§ 14083$ (West 2001). Other states quickly moved to clarify the legality of insurers' efforts to steer their insureds to selected providers.

14. Traditional health insurance permitted free choice of provider, largely because providers insisted that payers should not "practice medicine" by making choices for consumers. See Charles D. Weller, "Free Choice" as a Restraint of Trade in American Health Care Delivery and Insurance, 69 IOWA L. REV. 1351, 1351 (1984) ("[T]he AMA's free choice ethics, consistent with guild precepts, prevents providers from being split into groups competing over price. Market free choice, consistent with market principles, permits price as well as nonprice competition among providers."). The leading cases clarifying that collaborating professional competitors cannot prevent health plans from serving as purchasing agents for consumers include FTC v. Ind. Fed'n of Dentists, 476 U.S. 447 (1986) (upholding finding that dentists unlawfully restrained trade by agreeing not to provide x-rays that would allow insurers to review proposed treatments); Ariz. v. Maricopa County Med. Soc'y, 457 U.S. 332 (1982) (medical society's maximum fee controls held unlawful because "insurers are capable ... of obtaining binding agreements with providers [with respect to fees]"); Am. Med. Ass'n v. FTC, 638 F.2d 443 (2d Cir. 1980) (invalidating professional ethical codes that bar physician contracting with insurers).

15. Stephen Heffler et al., Health Spending Growth Up in 1999; Faster Growth Expected in the Future, HeAlth AFF., Mar./Apr. 2001, at 193, 194 ("Declines in price growth between 1988-93 and 1993-1998 account for more than two-thirds of the slowdown in spending growth."); David M. Cutler et al., How Does Managed Care Do It?, 31 RAND J. ECON. 526 (2000) (empirical study of experience with treating heart disease in Massachusetts, finding as follows: "HMOs reimburse only a little over half what indemnity insurance pays for the same procedure. But the rates of procedure use and adverse outcomes across plans are relatively similar.”). But see MARTIN GAYNOR ET AL., INCENTIVES IN HMOs (Nat'l Bureau of Econ. Research, Working Paper No. 8522, 2001) (reporting that financial incentives in one HMO induced saving of five percent in utilization costs). For the view that antitrust law itself needs to be further revolutionized by placing less emphasis on price competition and giving weight to the non-price (quality) dimensions of health care, see William M. Sage \& Peter J. Hammer, $A$ Copernican View of Health Care Antitrust, 65 LAw \& CONTEMP. PROBS. 241 (Autumn 2002).

16. It seems unlikely that health care providers will ever recapture the raw economic power they possessed when they were largely free to act as a cartel, policing the industry at key points. Even the 
prevented consolidation of hospitals and physician groups from restoring some of the providers' market power de facto. ${ }^{17}$ In addition, the counter-revolution against managed care has yielded new legal limitations on the freedom of health plans to select providers and to "deselect" them at will, subject only to contractual commitments. ${ }^{18}$ Plans are thus less able to negotiate low prices with individual physicians in return for an assured supply of patients and to demand cooperation with the plan and adherence to its policies.

In addition to fostering selective contracting, enforcement of the antitrust laws against professionals allowed health plans to adopt the practice of "predetermining" coverage. This method of rationing health care financing, which physicians resisted collectively with great success in the pre-antitrust era, ${ }^{19}$ is advantageous for several reasons. Not only does it allow plans to effectuate contractual limitations on coverage before costs are incurred, but it often enables plan medical directors to persuade the treating physician to prescribe a

Supreme Court's recent decision in Cal. Dental Ass'n v. FTC, 526 U.S. 756 (1999), which seemed to reopen doors previously closed to anticompetitive professional self-regulation, is not likely to change anything very much, although courts and plaintiffs may feel that more proof is now required to establish the illegality of certain restraints of trade. Major legislative change is also unlikely. Thus, although Congress recently entertained a proposal to create an antitrust exemption allowing physicians to engage in collective bargaining with health plans, the attention given that bill, mostly in the House of Representatives, probably reflected its value in procuring campaign contributions more than its actual appeal as a policy measure. See Carl F. Ameringer, Federal Antitrust Policy and Physician Discontent: Defining Moments in the Struggle for Congressional Relief, 27 J. HEALTH POL. POL'Y \& L. (forthcoming Aug. 2002) (examining politics of antitrust exemptions for physicians). Several states, relying on federal antitrust law's "state action" exemption, have authorized certain kinds of concerted action by providers under state supervision. E.g., N.C. Gen. Stat. §§ 131E-192.1-.13 (1996) (authorizing cooperative agreements by hospitals, including mergers); N.J. Stat. Ann. §§ 52:17B-196-209 (West 2002) (authorizing limited collective bargaining by physicians with health plans). See generally James F. Blumstein, Health Care Reform and Competing Visions of Medical Care: Antitrust and State Provider Cooperation Legislation, 79 CORNELL L. REV. 1459 (1994). These laws, however, are reported to have had only limited practical effect. James F. Blumstein, Assessing Hospital Cooperation Laws, 8 LOY. CONSUMER L. REV. 98, 105 (1995-96) (reporting few hospital mergers under such laws); Amy Snow Landa, N.J. Doctors Get Collective Bargaining Rights, AM. MED. NEws, Jan. 28, 2002, at 5 (reporting that, because New Jersey and similar states do not give physicians a right to strike, health plans have little incentive to bargain with them).

17. See Thomas L. Greaney, Whither Antitrust? The Uncertain Future of Competition Law in Health Care, HEALTH AFF., Mar./Apr. 2002, at 185 (observing some failures in antitrust enforcement in the health sector); Barbara Martinez, With New Muscle, Hospitals Squeeze Insurers on Rates, WALL ST. J., Apr. 12, 2002, at A1; Joseph Weber, The New Power Play in Health Care, Business WeEK, Jan. 28, 2002, at 90 (noting how managed care plans are losing the upper hand in negotiations over price and other issues, as providers merge and otherwise consolidate for bargaining purposes).

18. See, e.g., 24-A Maine Rev. Stat. § 4303 (2001); N.Y. Pub. Health L. § 4406-d (2001); Potvin v. Metropolitan Life Ins. Co., 997 P.2d 1153 (Cal. 2000); Harper v. Healthsource N.H., Inc., 674 A.2d 962 (N.H. 1996); Jill A. Marsteller et al., The Resurgence of Selective Contracting Restrictions, 22 J. HEALTH POL. POL'Y \& L. 1133 (1997). On state "any-willing-provider" laws, see Ky. Ass'n of Health Plans, Inc. v. Nichols, 227 F.3d 352 (6th Cir) (holding Kentucky law protecting providers' right to participate in health plans not preempted by federal law) cert. granted, 122 S.Ct 2655 (2002); CIGNA Healthplan, Inc. v. Louisiana ex rel. Ieyoub, 82 F.3d 642 (5th Cir. 1996) (holding Louisiana law preempted).

19. The necessary physician cooperation could not be obtained as long as physicians could collectively refuse to cooperate without fear of antitrust action. See United States v. Or. State Med. Soc'y, 343 U.S. 326, 336 (1952) (implying, in dicta, great antitrust tolerance for physician boycotts of payers pursuing practices objectionable to physicians). Cf. FTC v. Ind. Fed'n of Dentists, 476 U.S. 447 (1986). 
less costly course; indeed, many physicians modify their demands simply because they know a payer is watching. ${ }^{20}$ Predetermination of benefits is both cumbersome and controversial, however, especially if the treating physician is not committed to the plan and its agenda. ${ }^{21}$ Consumers have therefore enjoyed only limited savings from health plans' new ability to scrutinize physicians' clinical decisions. Predetermination of benefits also has been a particular target of one-sided media exposés and of legislation further hampering efforts by health plans to counteract moral hazard by strictly administering their contracts. $^{22}$

In the early days of the health care revolution, another breakthroughsecond in importance only to the antitrust initiative-threatened to embolden health plans in monitoring physicians. This development was the appearance of research showing that physicians' practice patterns varied substantially, and inexplicably, from place to place and that many customary clinical practices lacked convincing evidence of their efficacy in improving health status. ${ }^{23}$ A clear implication of these studies was that all was not well inside the black box of clinical medicine and that, contrary to what the medical profession had led the public to believe, much conventional practice lacked a scientific foundation. The revolutionary implications of these findings were clear, since they positively invited health plans to take managerial initiatives on behalf of their subscribers. Professional organizations, however, seeing the explosive possibilities, quickly took preemptive action to reestablish professional authority by promulgating authoritative "guidelines" for clinical practice. ${ }^{24}$ To be sure, the consuming public has benefitted from the medical profession's efforts to strengthen the scientific base of professional practice and from physicians' increasing recognition of an obligation to practice "evidence-based" medicine. But the

20. See generally Rosenberg et al., Effect of Utilization Review in a Fee-for-Service Health Insurance Plan, 333 NEW ENG. J. MED. 1326 (1995).

21. Physicians are sometimes said to have a duty to serve as "advocates" for their patients. If the physician has not accepted the legitimacy of a health plan's basic limitations on coverage, however, advocacy can be disruptive of plan efforts to control costs in the interest of its subscribers. See generally William M. Sage, Physicians as Advocates, 35 Hous. L. REV. 1529 (1999). On the other hand, a plan could and should expect its physicians to keep its contract administrators aware of all relevant facts (and their arguable clinical significance) in each case so that each patient gets what he has coming under his contract.

22. On restrictive state legislation, see generally Frank A. Sloan \& Mark A. Hall, Market Failures and the Evolution of State Regulation of Managed Care, 65 LAW \& CONTEMP. PROBS. 169 (Autumn 2002). See also infra Part V.D.

23. E.g., John M. Eisenberg, Doctors' Decisions and the Cost of Medical CARE: The REAsons FOR Doctors' PRACTICE PATTERnS AND WAys TO CHANGE THEM (1986); John E. Wennberg et al., The Dartmouth Atlas of Health Care in the United States (1996); Mark R. Chassin et al., Variations in the Use of Medical and Surgical Services by the Medicare Population, 314 New Eng. J. MED. 285 (1986); David M. Eddy, Clinical Policies and the Quality of Clinical Practice, 307 NEw ENG. J. MED. 343, 343 (1982) (finding "reason to believe that there are flaws in the process by which the profession generates clinical policies"); John E. Wennberg, Dealing with Medical Practice Variations: A Proposal for Action, HeAlTH AFF., Summer 1984, at 6.

24. See generally Institute of Medicine, Clinical PRACTICE Guidelines: Directions for A New Program (Marilyn J. Field \& Kathleen N. Lohr eds., 1990); Clark C. Havighurst, Practice Guidelines for Medical Care: The Policy Rationale, 34 ST. LouIs U. L.J. 777 (1990). 
profession's reassertion of authority over clinical practice perpetuated the old paradigm of medical care, which contemplates that choices will be driven solely by medical expertise, not by third-party middlemen or consumers' cost concerns. ${ }^{25}$ Thus, health plans, while free to enforce professional standards in predetermining coverage, are largely precluded from taking an independent hand in rationalizing health care spending to meet the needs of particular segments of the population. Consumers therefore remain locked in a system that gives them few real choices-few opportunities, that is, for significant economizing.

With only limited ability to ration financing explicitly through coverage decisions, health plans also seek to control costs by inducing their providersubcontractors to assume substantial financial risks for the care they undertake to provide. While this strategy lacks the openness and reviewability of explicit coverage decisions, the absence of transparency has proved a strength in practice, because providers' sub-rosa rationing of care is less likely to attract media criticism and political or legal attacks. ${ }^{26}$ Moreover, reformers principally interested in fostering organizational integration of financing and delivery generally find capitation and other incentive arrangements with subcontractors to be a positive development, since such methods of payment encourage collective responsibility for the cost as well as the quality of care. ${ }^{27}$ A market

25. See Havighurst, supra note 24 , at 785 ("[M]ost observers view the problems revealed by the new research strictly in accordance with the pure professional paradigm — as simply a rectifiable failure of scientific research, professional standard setting, and continuing medical education. Under this view, what is needed is simply more diligence by professional groups in determining what services work best and increased efforts to inform physicians of the conclusions reached. The assumption continues to be that, despite the demonstrated deficiencies of past performance, physicians left to their own devices with improved professional guidance will provide optimal care.”). For a recent reminder that physicians cannot be trusted not to overtreat patients for financial reward, see Jerome Groopman, A Knife in the Back, THE NEW YORKER, Apr. 8, 2002, at 66 (describing extensive use of unproved back surgery).

26. Challenges to provider rationing usually take the form of an ordinary malpractice claim against the provider for omitting precautions required by the standard of care. Several cases, however, have aimed, mostly unsuccessfully, at HMOs themselves for adopting incentive systems that arguably co-opt physicians, inviting them to engage in undue economizing. E.g., Pegram v. Herdrich, 530 U.S. 211 (2000) (rejecting challenge to physician incentives in HMOs); Maio v. Aetna, Inc., 221 F.3d 472, 499 (3d Cir. 2000) ("[W]e must decline appellants' invitation to pass judgment on the social utility of Aetna's particular HMO structure."); Ehlmann v. Kaiser Found. Health Plan of Tex., 198 F.3d 552 (5th Cir. 2000), cert. dismissed, 530 U.S. 1291 (rejecting class action attacking physician incentives); Shea v. Esensten, 107 F.3d 625 (8th Cir. 1997) (recognizing duty to disclose incentives); Weiss v. Cigna Healthcare, Inc., 972 F. Supp. 748, 753 (S.D.N.Y. 1997) ("[P]laintiff's concern about the soundness of managed care policy is best suited for resolution by branches of government other than the judiciary.").

27. E.g., Meredith B. Rosenthal et al., Managed Care and Market Power: Physician Organizations in Four Markets, HEALth AFF., Sept./Oct. 2001, at 187, 192 ("Many believe that the future of managed care lies in the devolution of clinical management and financial decision making to [physician organizations]."). In fact, many provider organizations accepting what is to a large extent an insurance risk have run into severe financial difficulties because they have underestimated the difficulty of managing such risks, particularly the difficulty of overcoming participating providers' resistance to cost-control measures. See id. ("[M]any of the physician organizations in the markets we visited had difficulty adapting to risk contracting because they lacked the proper systems and skills needed to manage risk effectively."). 
reformer might remain critical, however, because shifting financial risks to a variety of subcontracting providers largely deprives the health plan of the ability to implement a distinctive style of care, thereby differentiating itself from its competitors and giving consumers a meaningful alternative in the marketplace. In any event, risk contracting has been a widely used costcontainment tool in modern health plans. ${ }^{28}$

In general, it appears that the health care revolution did succeed in empowering consumers in at least one substantial way-by giving them agents who can both effectively negotiate with providers on their behalf over fees and procure care on something other than a fee-for-service basis. ${ }^{29}$ As a consequence of health plans' ability to force providers to compete on the basis of price, consumers pay less for their services than they would have paid under pre-revolutionary arrangements. In addition, the evidence suggests that these savings have been achieved with no net sacrifice in the quality of care. ${ }^{30}$ Consumers' gains stop there, however, for health plans never succeeded in parlaying their new freedom of action under the antitrust laws into substantial power over anything but price. They therefore remain largely unable to give effect to differing consumer preferences concerning the content, intensity, and quality of medical care. ${ }^{31}$ Moreover, there is scant interest among policy-makers in having them assume such responsibilities. Indeed, managed care plans are constantly scrutinized for signs that they offer services that are inferior in any way to services under traditional financing systems - the clear implication being that cost savings are appropriate only if they come at no sacrifice of quality. ${ }^{32}$ And, as will be seen, the professional paradigm of medical care, with its premise that any arguable benefit from health care is worth paying for, still dominates legal doctrine, political discourse, and media coverage. Thus, while the health care revolution has yielded some real cost savings for consumers, the revolutionary idea that consumers should be empowered to make choices

28. Today, however, provider entities are growing less eager to accept financial risk. James C. Robinson, The End of Managed Care, 285 JAMA 2622, 2624 (2001) ("Physician organizations are retreating from global capitation to partial capitation, case rates, or fee-for-service; are renouncing or losing authority for utilization review and claims processing; and are quietly abandoning the rhetoric of disintermediating the health insurance plans.").

29. A major problem in health care is the difficulty of defining discrete, uniform units of output for purposes of contracting and payment. See infra text accompanying notes 59-61. One major accomplishment of the purchasing revolution was the introduction of new payment methods besides fee-forservice, such as payment by capitation or by "diagnosis-related group."

30. See generally Gottfried \& Sloan, supra note 7.

31. This observation goes far toward explaining the finding of Cutler et al., supra note 15, that HMOs have not greatly modified clinical practice.

32. See Gottfried \& Sloan, supra note 7, at 137 (reviewing numerous studies comparing quality without appreciable allowance for cost differences and concluding that, even without regard to cost savings, managed care is "as fit for popular consumption as traditional, less affordable indemnity insurance"). Poorer quality in some areas is apparently acceptable if it is offset by quality improvements in other areas, so that net quality does not suffer. Neither critics of managed care nor analysts responding to their criticisms are inclined to fault managed care for failing to deliver on its promise to improve overall quality. 
involving consequential trade-offs in procuring health care has yet to gain traction either in health policy or in the marketplace.

Imperfect as they were, many of the specific tools that health plans developed for controlling costs in the revolutionary era are being blunted further by regulation or made subject to new liability risks poorly calibrated to real wrongdoing. ${ }^{33}$ Even though the political and legal backlash against managed care may not wholly disable health plans de jure as middlemen making choices on behalf of consumers, the managed care industry may interpret it as a definitive repudiation of their efforts to manage care independently as a service to their subscribers. ${ }^{34}$ Never very adventuresome or independent under the best of circumstances, managed care firms may now exhibit still more of the herdmentality characteristic of most heavily regulated industries. In industries where the parameters of competition are narrowly set by heavy governmental regulation, individual firms have too little independence or energy left to cater to the needs of consumers. ${ }^{35}$ In this climate, consumers are in danger of losing even more of the ground they gained during the health care revolution.

More important than the net ground gained by consumers, however, is the remaining distance left to the revolution's ultimate democratic goal-full empowerment of consumers. This article's next three sections examine some specific reasons why, despite early revolutionary changes in some rules of the health care game, today's health plans, the players upon whom consumers must rely to move the ball, have made few inroads into provider territory. It will be seen that health plans, though hefty enough for some defensive purposes, are poorly organized and slow afoot, have too few options in their play books, and are hampered by rules held over from pre-revolutionary days. They also have earned too little fan support to enjoy any kind of home-field advantage. Because health plans fall short in all of these respects, the great majority of today's consumers of health care have little to cheer about.

III

\section{HeAlth Plans’ FAILURE To InTEGRATE PROVIDERS AND FINANCING}

Virtually all of today's health plans are essentially general contractors, bearing some financial risk but well-distanced from the actual delivery of services. Thus, they remain merely payers, not providers of care capable of imposing effective control over providers' practices with a view to improving quality, realizing available efficiencies, and giving effect to their subscribers' preferences. Only the Kaiser-Permanente system seems to be integrated to

33. Sloan \& Hall, supra note 22; see also infra Part VI.D.

34. See, e.g., Robinson, supra note 28 , at 2627 ("[N]ever again will they succumb to the bait-andswitch gambit used by government and employers, who exhorted them to control health care costs and then vilified them for using the marketplace mechanisms that were at their disposal.").

35. Even if an industry member were tempted to strike out in a new direction, the new political and legal environment has made creative innovation even costlier and riskier for individual firms. No single firm is therefore likely to essay any controversial innovation that competitors could emulate once the first mover had cleared the way. 
such a degree and in such a way that it could, if it wanted, offer the public a uniform set of services reflecting well-founded, well-considered, and consistent policies for spending a fixed pool of premiums on health services for an enrolled population. Indeed, as promising as the Kaiser system once was as a model for reorganizing the health care industry, its continuing exceptionalism confirms the general rule that most health plans, even those nominally organized as HMOs, have little more ability to influence the actual hands-on delivery of care than indemnity insurers had in the earlier fee-for-service era. ${ }^{36}$ Although many of their subcontractors are themselves integrated in substantial ways, health plans remain generally unintegrated, presiding over an archipelago of subcontractors all doing very much their own thing within the range of what is professionally acceptable.

There are, to be sure, many obstacles to integrating both health care financing and providers in effective competitive units. For example, any health plan that is large enough to realize economies of scale in performing its core insurance functions, including marketing, risk spreading, and contract negotiation, would be likely to encounter substantial diseconomies of scale in attempting to manage care itself. ${ }^{37}$ The original Kaiser plan overcame this problem by employing a totally integrated physician group wholly dedicated to caring for Kaiser's enrolled population. And that business model probably succeeded only because Kaiser was able to begin small, in isolated environments, and to grow both its enrollment and its physician groups gradually over a long period without appreciable competition from health plans pursuing comparable strategies. Health plans of more recent vintage have been unable to get started in the same way, by home-growing comparable physician groups from scratch. ${ }^{38}$ Although some expected at one time that health plans

36. In 1998, Zelman and Berenson, two reformers discouraged by what they saw as a trend away from the hoped-for integration of financing and delivery, observed as follows:

$[\mathrm{T}]$ he most recent trends suggest that ... managed care plans may wind up watering down their products to such a degree that the potential for real coordination and for cost and quality control may be lost. Today much of managed care-with expanding networks of physicians and groups, easier access to specialists, and in some situations, less intrusive utilization review-is beginning to look and act ominously like the old fee-for-service system ....

Walter A. Zelman \& Robert A. Berenson, The Managed Care Blues and How to Cure THEM 12 (1998).

37. See Thomas Palay, Organizing an HMO by Contract: Some Transaction Cost Considerations, 65 NEB. L. REV. 728, 746 (1986) (noting that a "group practice can take advantage of close physician proximity to foster a strong social structure and communication network [with] norms ... established by example rather than by fiat," whereas looser, larger organizations "must rely more heavily upon formal processes, meetings, and rules"); James C. Robinson, The Future of Managed Care Organizations, HEALTH AFF., Mar./Apr. 1999, at 7, 18-19 (explaining "the economics of vertical disintegration" and observing, "[t]he administrative, information, and clinical competencies required for an organization that actually delivers health care are quite distinct from those of an organization that develops, markets, and monitors contractual networks"). Query whether information technology will eventually enable large health plans to coordinate care and monitor unintegrated physician networks and thus to deliver a uniform, customized products.

38. Staff model HMOs, in which physicians are essentially employees and fully integrated into the plan, either did not materialize or failed to prosper, partly because employers demanded greater freedom of choice for their employees. See generally ROBINSON, supra note 6, at 71-83. 
could achieve efficiency through loose affiliations and contractual relations with providers ${ }^{39}$ relationships created by such "virtual" integration proved unstable and prone to opportunism; they were also too attenuated to allow the plan to coordinate care and bring physician behavior into line with plan policy. ${ }^{40}$

In practice, it has proved nearly impossible for health plans other than Kaiser to engage physicians and other providers in long-term, committed relationships. In relating to health plans, physicians have strongly adhered to the traditional paradigm of medical care, under which they practice their profession in their own way, subject to professional norms alone, and payers are expected to support them without question in that endeavor. Moreover, most physicians and hospitals contract with managed care organizations only to fill their appointment books or beds, and they ensure their independence by contracting with as many plans as possible. The Kaiser system itself had difficulty recruiting physicians in the early years, succeeding only because it offered a unique practice option that a subset of physicians found attractive for personal or ideological reasons (or perhaps because they were foreign medical graduates lacking attributes necessary for easy success in the fee-for-service world). Early HMO proponents expected that certain preexisting medical groups, including multi-specialty group practices, hospital medical staffs, and faculty practice plans in academic medical centers, would be capable of operating as HMOs or the equivalent. Such groups, however, have proved generally unwilling to drop their lucrative fee-for-service business and commit themselves exclusively to serving as the sole provider for enrollees of a single plan.

A key reason why the hoped-for integration of physicians into competing health plans never occurred is that the marketplace still provides only weak incentives for improving the quality and efficiency of care. Because consumers are not good judges of the quality of the medical care they receive, health plans can advertise their interest in quality without actually doing very much to maintain or improve it. ${ }^{41}$ Moreover, the legal system, instead of filling this gap in consumer information by imposing legal liability on plans when quality fails, has remained true to the traditional paradigm, under which quality is a matter entirely between the provider and the patient. ${ }^{42}$ Interestingly, the Kaiser system

39. See, e.g., Jeff C. Goldsmith, The Illusive Logic of Integration, HEALTHCARE F.J., Sept.-Oct. 1994, at 26 (questioning the presumed benefits of much of the organizational integration sweeping the health care industry and suggesting virtual integration might serve as well); Clark C. Havighurst \& Glenn M. Hackbarth, Private Cost Containment, 300 New ENG. J. MED. 1298, 1299 (1979) (identifying "new opportunities for experimentation and change that lie on the broad-and largely unexploredspectrum from traditional financing mechanisms to ... [highly integrated] HMOs").

40. See generally RoBINSON, supra note 6, at 63-89.

41. Class action lawsuits have been filed charging HMOs with misrepresenting themselves to consumers on a number of points, including their commitment to quality. See In re Managed Care Litigation, 185 F. Supp. 2d 1310 (S.D. Fla. 2002); Clark C. Havighurst, Consumers Versus Managed Care: The New Class Actions, HEALTH AFF., July/Aug. 2001, at 8, 15-16 (describing and evaluating class action complaints charging HMOs with falsely advertising their commitment to quality).

42. The strength of the paradigm can be seen in Petrovitch v. Share Health Plan, Inc., 719 N.E.2d 756 (Ill. 1999), in which the court imposed vicarious liability for a physician's tort on an HMO-but 
picked up on the revolutionary idea that there should be a single locus of responsibility for both cost and quality at an early date, by voluntarily accepting corporate liability for provider malpractice. ${ }^{43}$ Thus, Kaiser's exceptionalism again reveals how the post-revolutionary marketplace omits the focused accountability necessary to realize the reformers' vision of improved health care.

It is hard to imagine a worse arrangement than allowing for-profit health plans to assume corporate responsibility for the cost of care while avoiding any legal responsibility for its quality. Yet this is precisely the situation that prevails today. ${ }^{44}$ Contrary to reformers' visions, virtually all of today's health plans, like health insurers in the fee-for-service era, remain essentially financers of care the content of which is decided upon for the most part by distant, nonexclusive subcontractors and the physicians they select. The health care revolution has thus failed to deliver on its promise to create organizational structures in which physicians cooperate with payers and with each other in managing both quality and cost in the interest of self-selected subsets of the consuming public.

IV

\section{Health Plans' Failure to OfFer Consumers Real ChOices}

Some critics of the old health care system hoped that integrating the financing of health care with its delivery not only would bring order out of chaos in clinical practice but would also allow consumers to treat health care more like an ordinary consumer good, choosing between expensive, ostensibly low-risk, high-quality care and cheaper styles of possibly lesser quality. ${ }^{45}$ Little progress has been made, however, toward creating competing entities capable of offering health care that is significantly differentiated along qualitative lines.

only because the plan attempted in modest, generally accepted ways to influence professional practice. The court clearly viewed vicarious liability as a punishment for plan interference with physicians, not as an inducement for plans to take an active interest in the quality of care being delivered by its subcontracting physicians. See generally Clark C. Havighurst, Vicarious Liability: Relocating Responsibility for the Quality of Medical Care, 26 AM. J. L. \& MED. 7 (2000) (observing that courts have not routinely imposed liability for provider malpractice on health plans but instead have generally left tort responsibility solely on individual practitioners and hospitals).

43. William M. Sage, Enterprise Liability and the Emerging Managed Health Care System, 60 LAW \& CONTEMP. PROBS. 159, 175 (Spring 1997).

44. Havighurst, supra note 42 , at 8 (observing and decrying this illogical arrangement and arguing for the establishment of, as a default rule, "the principle that a health plan is vicariously, and exclusively, liable for medical malpractice and other torts committed by health care providers whom it procures to treat its enrollees"); Havighurst, supra note 41, at 17 (opining that, in pending class actions, "a material misrepresentation might be found when a plan advertises a general commitment to quality while systematically denying any legal duty to maintain it"). Given the prevailing insulation of health plans from tort liability, it is surprising that quality is no worse than under fee-for-service financing; indeed, better management should improve quality rather than merely maintain it.

45. See sources cited supra note 3. For the argument that offering such choices is the principal raison d'être of private financing of health care and that, without choice, the case for maintaining a private system with high administrative costs is weak, see Clark C. Havighurst, Why Preserve Private Health Care Financing?, in AMERICAN HEALTH POLICY: CRITICAL ISSUES FOR REFORM 87 (Robert B. Helms ed., 1993). 
To be sure, some subcontractor-providers are organized and paid in ways that permit and encourage substantial economizing. But their undertaking to the health plan and its enrollees is only to provide care in accordance with general community standards, and their distance from the health-plan general contractor does not allow the latter either to manage care directly in pursuit of objectives of its own or to transmit its subscribers' preferences effectively to the actual providers of care. ${ }^{46}$ Only the Kaiser system is organized in a way that might allow it to manage providers in pursuit of a plan-defined mission. Without competition from plans with similar capabilities, however, Kaiser has never found it necessary to offer contracts expressly differentiating its promises from those of other health plans. Organizational barriers separating health plans from physicians are thus one apparent reason why all health plans offer consumers essentially the same core coverage (all "medically necessary" services) and the same nominal quality of care (whatever professional standards require). ${ }^{47}$

There may be other, more fundamental reasons, however, why health plans have not catered to the desires of individuals willing to accept some risk in return for significant cost savings. One might doubt, for example, that there is any significant demand for low-cost health coverage involving explicit assumption of risk; after all, consumers already have the option of going without coverage altogether, saving the entire cost of purchasing protection by taking their chances with the so-called "safety net." But, even though millions of Americans have in fact chosen to free ride on society's good nature in this way (or to accept employment that does not offer health coverage as a fringe benefit) ${ }^{48}$ there is another large group of individuals for whom health coverage is an integral part of their compensation and who can save no more than a fraction of its cost by refusing it. Many, perhaps even a majority, of these individuals are undoubtedly paying more than they would choose to spend if

46. Although plans sometimes impose modest requirements related to preventive services or other measurable features of health care quality, they have rarely sought to ensure a generally high level of performance or to make their providers' practices more uniform by coordinating their efforts and rationalizing their clinical methods. See RoBINSON, supra note 6, at 115 ("[C]ontinuous quality improvement ... is coming only slowly to medical care."). Instead, any efforts they make to manage clinical care are generally limited to some provider profiling, monitoring of the provision of certain preventive services, occasional efforts to steer patients to "centers of excellence" for highly specialized services, and imposing modest reporting and quality-related requirements on subcontractors. Few plans have been notably selective in their choices of subcontractors, screening for demonstrated competence and demanding organizational changes necessary for superior performance. Instead, most plans are pleased to cover the services of any generally cooperative provider willing to accept the plan's financial terms.

47. See infra notes $57,63-69$ and accompanying text.

48. See Jeff Bailey, Small Businesses Consider Cuts in Health-Care Benefits, WALL ST. J., Dec. 18, 2001, at B4 (citing a study by the Kaiser Family Foundation and Health Research and Educational Trust: "[W]hile $99 \%$ of employers with 200 or more workers offer insurance, just $66 \%$ of the employees are covered by those plans. At companies with fewer than 200 workers, while $65 \%$ offer coverage, just $59 \%$ of workers are covered."). It is not clear how many employees rejecting coverage may possess it through a spouse. 
reasonable economizing opportunities were offered. ${ }^{49}$ If everyone faced the full cost difference between high- and low-cost coverage, there would certainly be some takers for the bare-bones variety. ${ }^{50}$

Offering real health care choices is sometimes ruled out on the ground that it would segment the risk pool and destabilize the insurance market-as insurable consumers, with superior knowledge of their own future needs, seek to outsmart sellers of coverage. One concern is that poorer risks will gravitate toward the most generous health plan, eventually causing a spiral in which that plan's increasingly high premiums drive all the still-insurable risks into lowercost plans. ${ }^{51}$ Employers and others managing the menu of choices could address this potential problem, however, by severing the automatic link between the premiums paid by individuals and the revenue each plan receives; thus, premiums could be set realistically and then pooled, and distributed according to the risk profile of each plan's enrolled population. ${ }^{52}$ Under such an arrangement, plans offering higher-quality coverage would remain pricecompetitive for healthier consumers seeking maximum protection, and all plans would be rewarded in some measure for appealing to higher risks. Another fear associated with offering real choices is that adverse selection would result if consumers could upgrade their coverage whenever a major health problem loomed; this problem could be ameliorated, however, "simply by allowing a higher-priced plan that an enrollee seeks to join to restrict its coverage of any preexisting condition to that provided under the enrollee's previous plan." ${ }^{53}$ Finally, it is possible that "niche" health plans designed for a lower-income or risk-tolerant minority might be too small to achieve vital economies of scale in many areas of plan administration. In any event, the concept of offering consumers real choices has never been put to a true market test-for a variety of practical reasons explored below.

\section{A. Hidden Costs, Employer Choices}

A key reason for the low level of apparent consumer interest in low-cost health care is the insulation of consumers from most of the cost of whatever coverage they obtain. Heavy tax subsidies, in the form of exclusions of

49. See infra text accompanying notes $102-113$.

50. But see Mark A. Hall, Reforming Private Health insurance 57 (1994); Families USA, No SALE: THE FAILURE OF BAREBONES InSURANCE (1993). These sources report that very few employers opted, when it was offered, for health insurance without certain state-mandated benefits and with arbitrary dollar or other caps on coverage. However, no plans have offered contracts explicitly and substantially curbing entitlements to marginally beneficial care, as proposed in HAVIGHURST, HEALTH CARE CHOICES, supra note 3, at 157-302.

51. See generally DAVID M. Cutler \& Richard J. ZeckHAuser, AdVERSE SElection IN HeAlth Insurance (Nat'l Bureau of Econ. Research, Working Paper No. 6107, 1997).

52. Adjusting payments to reflect risks, however, is more easily proposed than done. See, e.g., Joseph P. Newhouse, Risk Adjustment: Where Are We Now?, 35 INQUIRY 122 (1998); Symposium, Private Employers and Risk Adjustment, 38 INQUIRY 242 (2001). But see CUTLER \& ZECKHAUSER, supra note 51 (reporting real-world experiences with adverse selection and suggesting possible responses by employers in pricing coverage to individuals).

53. HAVIGHURSt, HeAlth CARE CHOICES, supra note 3, at 53. 
employer-paid premiums from the bases on which income and payroll taxes are levied, make employer-purchased health coverage a substantial bargain for consumers; only through that route can all health bills be paid with untaxed dollars, yielding effective discounts of more than forty percent for some taxpayers (depending on applicable federal and state tax rates). ${ }^{54}$ In addition, because most tax subsidies apply only when coverage is procured through an employer, most individuals have employer-based coverage. Most employers, however, design their health benefits with the average worker, not individuals, in mind. ${ }^{55}$ Moreover, only a generous plan sends workers the message most employers want to convey about their concern for employee welfare. For this reason, and also because health benefits are useful in attracting and keeping workers with the best chances of being hired by someone else, employee health plans are likely to be costlier than even the average worker would demand (even with tax subsidies enhancing his purchasing power).

While the interest of some employees in purchasing cheaper coverage is often lost in the politics of employer/employee relations, some employers do offer choices that may appeal to lower-income workers. A limited number go so far as to offer fixed contributions, allowing individuals to select a health plan from a menu including low-cost options and requiring them to pay the full difference between the predetermined employer payment and the plan's actual premium. $^{56}$ The more common pattern for employers offering multiple health plans, however, is to require employee contributions reflecting only part of the cost differences among them. Another popular approach has been to offer employees a single plan of the "point-of-service" variety. Such plans charge everyone the same premium for access to the plan's limited provider network, but then allow individuals to elect care from non-network providers at a substantial additional cost. In these plans, lower-income persons have the option of staying within the system, thus enjoying some savings.

Although structuring employee benefits in any of the foregoing ways allows employees desiring somewhat cheaper coverage to have it, none of these approaches leaves consumers with either strong incentives to economize beyond a certain arbitrary point or reasonable opportunities for doing so. Even in fixed-contribution plans, employers are likely to set their contributions at a relatively high level, because only the employer-paid portion of the premium enjoys the favorable tax treatment that better-paid employees especially covet. Moreover, even though one or more plans offered by an employer might be significantly cheaper than others, all plans (including point-of-service ones) feature the same nominal entitlement within each category of coverage-a right

54. See id. at 100-03. Even with tax subsidies inflating demand for comprehensive (even firstdollar) coverage, however, reliance on market forces is not an implausible policy. Id. at 102 (observing that even very heavy tax subsidies encouraging investment in personal residences have not disabled the market for housing).

55. See generally Alain C. Enthoven, Commentary-The Fortune 500 Model for Health Care: Is Now the Time to Change?, 27 J. HeAlth POL. POL'Y \& L. 37 (2002).

56. Id. at 45. 
to receive all "medically necessary" care meeting professional standards, as determined and enforced by courts. ${ }^{57}$ The cost differences among them therefore reflect, not explicit qualitative differences in the care underwritten or provided, but only different categorical exclusions, different cost-sharing requirements, different physician networks, different coverage of out-ofnetwork care, and so forth. Unless and until a critical mass of employers offer benefits in forms that invite real economizing at the core of clinical practice, consumers whose welfare would be enhanced by purchasing revolutionary lowcost coverage will find no health plans offering it.

Alain Enthoven has bemoaned how few employers today offer their employees a range of health care choices with appropriate price tags attached. ${ }^{58}$ He has also noted employers' expedient reasons for their various practices. In part, however, the impulse of most employers to give all their employees access to care meeting the same qualitative standard probably reflects a felt need to preserve egalitarian appearances. Although employers feel comfortable in offering alternative plans featuring different cost sharing or different limits on a patient's freedom to choose a provider, most would quickly reject the idea of offering, as an option that some employees might feel compelled to choose, a plan with substantive entitlements explicitly inferior to those preferred by better-off employees. Thus, even though employees today may have some range of choice, they are deprived of options that many of them might prefer. To be sure, how far the choices available to today's consumers fall short of meeting their personal needs is an unanswerable empirical question. The health care revolution, however, has not succeeded in giving them anything approaching the same control over their spending for health care that they have over other expenditures they make. Thus, health care is still rather far from being a true consumer good on which consumers can reasonably economize when times are bad or when other needs predominate.

\section{B. The Difficulty of Customizing Health Care Contracts}

Another reason why explicit qualitative differences have not appeared in the market for health care and health coverage may be the difficulty health plans would face in trying to articulate in administrable contract language any standard other than the dominant professional one. ${ }^{59}$ The product a health plan

57. See infra notes 59-69 and accompanying text. "Medical necessity" is the standard universally employed in determining patient entitlements. Obviously derived from the any-benefit-is-worthpaying-for principle embodied in the professional paradigm, it is generally applied in practice by reference to professional standards. See generally SARA Singer ET AL., CENTER FOR HeAlth PoliCY, STANFORd UniVERsity, DECREASING VARIATION IN MEDICAL NECESSITY DECISION MaKing (1999); Linda A. Bergthold, Medical Necessity: Do We Need It?, HEAlTH AFF., Winter 1995, at 180. A criticism of its universal use can be found in HAVIGHURST, HEALTH CARE CHOICES, supra note 3, at 143-47.

58. Enthoven, supra note 55.

59. This was a better excuse in the early days of health insurance than it is today:

Although adopting professional standards by reference was once an efficient way to write health care contracts, the universal use of contracts written in this way eventually created a 
sells is, after all, entirely intangible-only a contractual undertaking to deliver (or finance) certain health services (of a particular quality) under certain contingencies. A health plan could offer economical alternative coverage, therefore, only by explicitly contracting with its subscribers in ways that effectively limit both its own payment obligations and the legal duties of its providers. Whereas ordinary commercial contracts for the future delivery of goods or services generally incorporate detailed specifications of the deliverables, it would be very difficult to write a health care contract effectively specifying the obligations of the plan and its providers under all the circumstances that might arise. ${ }^{60}$ Whether for this reason or others, postrevolutionary health plans still define most of their own and their providers' obligations only by reference to professional standards. ${ }^{61}$

The drafting problem, however, is not the only or even the principal reason why health care contracts have not been written to give consumers significant economizing options. ${ }^{62}$ A greater obstacle to the offering of low-cost health care has been the U.S. legal system. ${ }^{63}$ Even as national health policy seemed to be entrusting choices to consumers and their agents, no one thought to instruct the courts to replace the old professional paradigm of medical care with a new paradigm based on consumer choice and private contract. ${ }^{64}$ It thus remains

market without elementary financial constraints on the proliferation of new medical technologies and the evolution of professional standards. Not only did medical care become stunningly expensive under the incentives thus created, but the law's compulsions, derived from customary practice, increasingly lost touch with economic rationality. Ironically, contracting methods that were arguably in the consumer's interest when they were first adopted ultimately undercut the utility of health care contracts as tools for cost containment. There is good reason, therefore, for contract drafters to reconsider their long-standing convention of letting the medical profession and the courts finally define payer and provider obligations.

HAVIGHURST, HEALTH CARE CHOICES, supra note 3, at 117.

60. Incomplete or ambiguous contracts would not, however, be unique to health care. See generally David Charny, Hypothetical Bargains: The Normative Structure of Contract Interpretation, $89 \mathrm{MICH}$. L. REV. 1815 (1991). A possible solution in the health care context would be a fully articulated set of procedures for consistently administering the contract, subject to judicial review only for abuse of discretion. See, e.g., HAVIGHURSt, HeAlth CARE ChOICES, supra note 3, at 200-14; see also infra note 118.

61. Although some things such as cosmetic surgery or "experimental" treatments are typically excluded from coverage categorically, outside these excluded categories, health care contracts generally cover all services deemed "medically necessary." See supra note 57.

62. For suggestions on how better contracts might be written, see HAVIGHURST, HeALTH CARE CHOICES, supra note 3, at 157-221. See also infra Part VII.

63. See generally Havinghurst, Health Care Choices supra note 3, at 303-30; Mark A. Hall \& Gerald F. Anderson, Health Insurers' Assessment of Medical Necessity, 140 U. PA. L. REV. 1637 (1992); Clark C. Havighurst, Prospective Self-Denial: Can Consumers Contract Today to Accept Health Care Rationing Tomorrow?, 140 U. PA. L. REV. 1755 (1992).

64. But see Clark C. Havighurst, Decentralizing Decision Making: Private Contract versus Professional Norms, in MARKet Reforms in HeAlth CARE: CurRent Issues, New Directions, STRATEGIC DECISIONS 22 (Jack A. Meyer ed., 1983). In this early article about the emerging revolutionary challenge to "the prevalent assumption that the health care system must operate under prescriptive standards of acceptable care and appropriate spending," id., I warned would-be market reformers of the health care system, who were then in a somewhat triumphant mood, that they "could go wrong ... by assuming too readily that interacting private parties and institutions would be free and 
conventional today, just as it was before the antitrust revolution, for courts to look solely to consensus and custom in the medical community to find the standards they use in judging medical negligence or in defining the obligation of a health plan to pay for physician-prescribed services. ${ }^{65}$ Although this source of benchmarks is regularly incorporated in private contracts, either by implication (as in the typical, unwritten physician/patient contract) or by explicit reference (as in the common commitment to cover all "medically necessary" services), the universal acceptance of professional standards is in no sense voluntary. Health plans have simply been unable to rely on courts to enforce, or to enforce according to its intended terms, any contract purporting to set any standard other than a professional one. ${ }^{66}$ Although drafting an alternative standard would certainly be difficult, it would be still harder to get courts consistently and routinely to allow contractually authorized departures from professionally dictated norms. Without freedom of contract as a safety valve to release the pressure on providers and plans to provide only high-cost, conventional care, the legal system stands as a major obstacle to empowering consumers and completing the health care revolution.

The legal system's unshakable attachment to professional standards is ironic in light of the evidence that much conventional medical practice lacks a solid scientific foundation. ${ }^{67}$ In addition, because professional standards have evolved with little need to compare health benefits and economic costs, they have no presumptive claim to represent either efficient practice or sound public policy. Nor have they ever been explicitly adopted as binding regulatory standards through the democratic political process. Instead, the common law system has simply embraced the medical profession's preferred paradigm of medical care,

uninhibited in their competitive efforts to translate consumer cost concerns into economizing behavior by providers" Id. Expanding on ideas first expressed by Richard A. Epstein, Medical Malpractice: The Case for Contract, 1 AM. B. Found. RES. J. 94 (1976), the article raised doubt about the flexibility and utility of private contracts as vehicles for introducing alternative standards, rights, and obligations in the health care field. As I feared, the need to ensure freedom of contract was indeed below the radar of policy-makers, whose main concern in deregulating the health care sector was only to roll back explicit command-and-control regulation. Yet, as I observed,

[d]octrines of private law-the law of torts and contracts-may impose on private parties duties that are inconsistent with both efficiency and the parties' contractually specified obligations. If such legal doctrines, originally designed to prevent economically powerful interests from overreaching the consumer, stand in the way of departures from prevailing standards of care and practice in the medical care field, market reformers' hopes of seeing consumers offered a full range of choice are doomed to frustration.

Havighurst, supra, at 23 (emphasis added). It is ironic that legal doctrines ostensibly designed to protect consumers against "economically powerful interests" so effectively turned back the health care revolution's move to enable consumers to contest the powerful dictates of both law and medicine, thereby perpetuating "The Tyranny of Professional Norms and Standards." Id.

65. For observations and materials relating to professional standards as (costly) legal standards, see Clark C. Havighurst et al., Health Care law and Policy: Readings, Notes, and QUESTIONS 191-204, 999-1070, 1228-38 (2d ed. 1998) (examining both malpractice law and coverage issues). See also Havighurst, Health CARE Choices, supra note 3, at 111-17.

66. See generally Hall \& Anderson, supra note 63; HAVIGHURST, HEAlth CARE CHOICES, supra note 3 , at $304-30$.

67. See supra notes 23-25 and accompanying text. 
which insists on treating all clinical choices as purely technical ones and denies the legitimacy of balancing benefits and costs. ${ }^{68}$ Indeed, although physicians regularly malign the legal system in the United States, it has remained their best defense against revolutionary forces threatening to lessen both their standardsetting authority and general demand for their costly services. By unthinkingly giving normative effect to professional standards as more than default rules escapable by contract, the law has prevented the health care revolution from liberating consumers from the dictates of a professional monopoly. ${ }^{69}$

\section{V}

\section{HeAlth Plans' FAILURe to EARn CONSUMERS' Trust}

A third way in which the health care revolution failed to achieve its democratic objectives was in not giving consumers new representatives whom they could trust to execute their wishes. Even though early proponents of HMOs and other reforms envisioned that health plans would be valuable allies of consumers in battling high health care costs and entrenched professional power, the political backlash against managed care in the 1990s revealed that the health care revolution never gained favor among the ordinary citizens whom it was supposed to benefit. Indeed, today's consumers/voters seem quite ready to see their health plans put under new regulatory constraints and new threats of legal action. ${ }^{70}$ An important question is why health plans, newly empowered by the revolution of the late 1970s, never gained enough public trust to carry out crucial elements of their mission in a market-driven health system.

In part, the problem was that health plans achieved commercial success too easily in the 1980s. Thus, they were able to earn high profits, not by reforming themselves or the health care system in accordance with revolutionary

68. See supra notes 8, 63-65; see also Helling v. Carey, 519 P.2d 981 (Wash. 1974). In the latter famous case, the Washington Supreme Court rejected a customary standard of care that reflected actual market choices by cost-conscious consumers (of routine eye exams, a service not widely covered by insurance) and required instead that, whatever the added cost, ophthalmologists must adhere to the standard generally prevailing for insured services, where moral hazard operates and cost is no object. Thus, under Helling, if a service might yield a benefit to the patient, it is negligent for the physician to omit it.

69. "It is simply ironic that the same legal system that with one arm launched an antitrust initiative successfully challenging overt efforts by the medical profession to exercise decision-making authority has with its other arms given medical interests a monopoly over the most important economic decisions affecting American health care." Clark C. Havighurst, American Health Care and the Law-We Need to Talk!, HeAlth AFF., July/Aug. 2000, at 84, 97.

70. See Robert J. Blendon et al., Understanding the Managed Care Backlash, HEALTH AFF., Jul./Aug. 1998, at 80 (reporting public dissatisfaction with managed care in general, despite overall satisfaction with their own plans). Findings such as those reported by Blendon and his colleagues suggest that political support for patient protection legislation, while seemingly wide, is not as strong as the media make it appear. See also Fred Barnes, Patients' Bill of Goods, WEEKLY STANDARD, Aug. 6, 2001, at 11 (reviewing polling data). It is notable in this context that Congress has been more eager to entertain legislative proposals than to pass them, perhaps because supporters find the issue a good one on which to posture and because both sides find it a lucrative source of campaign contributions. On the prospects for such legislation in 2002, see Havighurst, supra note 1, at 3-4 n.12. 
principles, but simply by negotiating lower payments to providers, selecting only better risks (healthier enrollees) in forming risk pools, and discouraging expenditures that were wasteful by any standard. With pickings so easy, there was no need for health plans to essay significant innovation in organizing providers, in educating consumers concerning the benefits of new arrangements, or in writing heretical contracts. In addition, consumers could not see HMOs' vaunted accomplishments. Reported cost savings, for example, appeared to accrue only to employers, plan shareholders, or well-paid CEOseven when they were in fact passed on, unlabeled (and therefore taken for granted), in higher take-home pay. Consumers also looked largely in vain for quality improvements and for increased responsiveness to their own concerns. Because their early success came so easily, health plans failed to lay a foundation, or to prepare consumers, for a future when cost savings would come harder and be more controversial.

Politically, too, the managed care industry took the easy path and failed to build constituencies that would support it against counter-revolutionary forces. Taking their cues mostly from employers (their immediate customers) and from the friendly political environment of the 1980s, managed care firms saw no need to cultivate the understanding and confidence of ordinary consumers. Their message, like that of the medical profession in an earlier era, was essentially, "trust us"-which the public ultimately refused to do. Without solid consumer support, managed care plans proved to be political pushovers as soon as the public began to scrutinize their manner of doing business. And politicians proved fickle as soon as public opinion turned sour. The goodwill that managed care firms initially enjoyed without having to earn, and then arguably squandered, will be difficult to regain.

Mistrust of the managed care industry among influential opinion-makers was inspired in large part by health plans' insulation from normal legal accountability for injuries their erroneous decisions might cause to patients. The federal Employee Retirement Income Security Act of 1974 ("ERISA") "1 was construed to preempt both state regulation and state legal remedies against health benefit plans maintained by private employers. ${ }^{72}$ Therefore, because federal law, including ERISA itself, provided only weak protections and remedies, managed care plans were left free to pursue their cost-containment

71. 29 U.S.C. $\$ 1001$ (2000).

72. Ingersoll-Rand Co. v. McLendon, 498 U.S. 133, 142 (1990) (citing Congress's goals of "ensur[ing] that plans and plan sponsors would be subject to a uniform body of benefits law" and "minimiz[ing] the administrative and financial burden of complying with conflicting directives among States or between States and the Federal Government"); Pilot Life Ins. Co. v. Dedeaux, 481 U.S. 41, 47-48 (1987) (holding that common law tort and contract causes of action seeking damages for employer's disability insurer's improper processing of a claim are preempted by ERISA); Bast v. Prudential Ins. Co. of America, 150 F.3d 1003 (9th Cir. 1998) (holding that ERISA preempted patients' survivor claims for denial of coverage for autologous bone marrow transplant and related treatment); Corcoran v. United Healthcare, Inc., 965 F.2d 1321 (5th Cir. 1992) (holding claim against employerretained benefits manager preempted by ERISA). This effect of ERISA was wholly unanticipated by Congress. See infra note 74. 
agendas without much risk of liability to angry patients. ${ }^{73}$ In some respects, ERISA advanced the agenda of the health care revolution by allowing selfinsured employers and firms administering employee benefits to undertake innovations in cost containment without permission from conservative state insurance regulators and without facing other legal risks. ${ }^{74}$ But health plans' success in bringing themselves within ERISA's protections also made them susceptible to valid criticism and successful political attacks, eventually turning what appeared to be a legislative blessing into a political curse. If ERISA had not insulated health plans from damage claims when they misuse their power to ration financing, health plans might have been more candid in explaining themselves to consumers and more careful in crafting their contracts.

In retrospect, it seems that health plans could have avoided many of their recent political problems if they had built their defenses on the merits-in the marketplace and in their contracts with consumers-rather than on the unstable sands of early political popularity, employer support, and ERISA preemption. ${ }^{75}$ To be sure, managed care plans could never have carried out the revolutionary agenda in full as long as consumers were effectively shielded from seeing (though not from paying) much of the cost of their own health care. But the purveyors of managed care made many mistakes in designing and marketing their products. Instead of building on the revolution's premises, managed care plans proceeded on the assumption that, because they had been endorsed by employers and policy-makers, their methods constituted, and would be viewed as, the wave of the future. ${ }^{76}$ On this basis, they confidently curtailed consumers' traditional entitlements without such niceties as adequate disclosure of their business methods or contracts authorizing their use. ${ }^{77}$ Although the methods

73. See generally Peter Jacobson \& Scott Pomfret, Form, Function, and Managed Care Torts: Achieving Fairness and Equity in ERISA Jurisprudence, 35 HOUS. L. REV. 985 (1998).

74. Ironically, ERISA was not meant to be part of any revolutionary agenda in health care, for it was enacted well before the market option was recognized as a plausible reform strategy. Moreover, Congress passed it to reform the management of pension funds, not health care. Before ERISA, employers generally provided health coverage through conventional insurance, the state regulation of which ERISA's so-called "saving clause" specifically excepted from its preemptive reach. 29 U.S.C.A. $\S 1144$ (b)(2) (2000). Unintended consequences resulted, however, when most employers large enough to do so began to self-insure their employees' health benefits, thus escaping both the burdens of state insurance regulation and the impact of other state laws applicable to health insurers. In addition, the Supreme Court added to ERISA's preemptive scope by permitting free-standing health plans such as HMOs (as well as self-funded employer plans) to invoke preemption when they were administering employer-purchased benefits. See Pilot Life, 481 U.S. at 47-48 (recognizing "no dispute" that-and stating that "undoubtedly"-an employer's independent disability insurer could invoke ERISA preemption unless the saving clause applied). Only recently has the saving clause been construed broadly enough to restore most of the states' regulatory authority over such plans. Rush Prudential HMO, Inc. v. Moran, 122 S. Ct. 2151 (2002). See note 125 infra.

75. See generally Havighurst, supra note 41 (finding possible merit in consumer class actions alleging nondisclosure, misrepresentation, and fiduciary breaches by HMOs in presenting themselves to consumers).

76. See Havighurst, supra note 1, at 6-7 n.18.

77. Robinson, supra note 28 , at 2623 ("[T] he fundamental flaw of managed care, in retrospect, was that it sought to navigate the tensions between limited resources and unlimited expectations without explaining exactly how it was so doing."). 
they employed were generally accepted in policy circles, they were bound to be misunderstood by the general public if not carefully explained in advance. ${ }^{78}$ Nevertheless, consumers were never told that there are trade-offs in health care (as in the rest of life), or that low premiums (and higher take-home pay) depend on preventing individual providers and patients from drawing too freely on the premium pool. Instead, consumers were encouraged to believe that nothing important had changed in their legal entitlements or in their relationships with physicians. $^{79}$

It is at least possible that health plans could have avoided extreme public mistrust if they had approached consumers honestly and as sovereign decision makers - in the democratic spirit of the health care revolution. Legitimacy in the public eye might have been achieved by offering consumers clear choices among well-explained alternatives bearing price tags roughly reflecting their qualitative differences. Reasonable agreements entered into ex ante might therefore have been easier to enforce when regrets arose ex post. And wellcrafted contracts might have provided legal warrants for cost-control measures that are entirely defensible as responses to moral hazard, but hard to defend under the populist-cum-professional view of health care held by all plaintiffs' lawyers and, apparently, by most journalists, politicians, physicians, judges, and juries. In any event, because the health care revolution failed to produce a new regime of trustworthy decision-makers, it was relatively easy for revanchist interests to preserve or restore essential elements of the old order.

\section{VI \\ WHY THE REVOLUTION NEVER HAD A CHANCE: The Political ECONOMY OF HeAlth CARE LAW AND POLICY}

Modern health plans are only partly responsible for the shortfalls of the health care revolution, since most of their failings reflected cultural, economic, regulatory, and legal conditions that they could neither ignore nor easily change. Thus, health plans' public relations and marketing appeals had to recognize the extent to which consumers, insulated from health care costs, wanted only soothing promises, not opportunities to economize by accepting apparent health risks. In addition, on advice of counsel, health plans undoubtedly felt legally bound to finance all care meeting professional standards rather than acting as surrogate economizers for their subscribers. Indeed, the legal system, after initiating antitrust enforcement in the 1970s, never embraced the cognate market principle that consumers should be free to make potentially consequential choices about their own health care. As a result, the United States never really came close to forging the chain of public

78. Id. at 2627 ("The strategy of giving with one hand while taking away with the other, of offering consumers comprehensive benefits while restricting access through utilization review, obfuscates the workings of the system, undermines trust between patients and physicians, and has infuriated everyone involved.").

79. See generally Havighurst, supra note 41, at 14-21. 
policies necessary to empower consumers to purchase health care according to their respective needs and circumstances. ${ }^{80}$

This section of the article explains the legal and political consensus that strongly supports prescriptive regulation of health care and the systematic hiding of health care costs from those who pay them. This explanation is necessary to complete the article's assessment of why, despite the hopes of some early visionaries, no real revolution ever occurred in American health care.

\section{A. The Crucial Moral Hazard}

The conventional justification for imposing heavy doses of judge-made law and regulation on the health care sector is the inability of consumers to gauge the quality of care, which may make it impossible for a free market in health services to produce efficient results. ${ }^{81} \quad$ Notwithstanding the availability of middleman-agents who could supply much of the sophistication that individual consumers inevitably lack, the political/legal culture is powerfully committed to this market-failure rationale for not letting ordinary people face trade-offs between cost and quality. Significantly, however, neither government nor the legal system has stepped into consumers' shoes and accepted responsibility for making better-informed economic choices about health care on their behalf. To the contrary, law and public policy still embody the medical profession's preferred paradigm of health care, under which cost considerations are largely excluded from all judgments except insofar as the profession itself may recognize their relevance. The market-failure rationale is thus less of a justification for limiting freedom of contract than a pretext for keeping ultimate authority in professional hands-medical or legal, as the case may be.

On reflection, it should be obvious that the market failure most responsible for economic inefficiency in the health care sector is not consumers' ignorance about the quality of care, but rather their ignorance of the cost of care, which ensures that neither the choices they make in the marketplace nor the opinions they express in the political process reveal their true preferences. Virtually everyone involved in the never-never land of health care thinks-rightly in some cases, wrongly in others - that someone else will pay the bill, including whatever costs law and legislation may impose. Consumers believe that most of the cost of health care, beyond the fraction they may see as their own contribution, is borne by their employers, rich insurance companies, or the government. On the other hand, employers know differently-that, although they may write the checks for coverage, cost increases are ultimately borne

80. See supra notes $64,69$.

81. See, e.g., Kenneth J. Arrow, Uncertainty and the Welfare Economics of Medical Care, 53 AM. ECON. REV. 941, 951-52, 965-67 (1963); Russell Korobkin, The Efficiency of Managed Care "Patient Protection Laws": Incomplete Contracts, Bounded Rationality, and Market Failure, 85 CORNELL L. REV. 1 (1999). 
mostly by the employees themselves in the form of lower wages. ${ }^{82}$ Insurers and health plans, for their part, know they can charge greater premiums to cover any higher costs that regulation entails as long as their competitors face similar increases; indeed, demand for coverage may be so price-inelastic that new regulations will actually increase their revenues even though some current customers are forced to drop or reduce coverage. Legislators know that, except in maintaining public financing programs, they do not have to levy taxes to pay the cost of complying with regulatory mandates they impose on health plans ${ }^{83}$ they can also expect that more voters will praise them for imposing high standards than will penalize them for the cost increases that such standards entail. Judges and juries, of course, are even less accountable for costs they cause the health care industry to incur and consumers to pay.

The consequence of the shell game in which costs are moved wherever employees/consumers/voters are not looking is that medical practice and health care plans are pervasively overregulated in the United States-that is, subject to legal prescriptions that make sense only because price tags have been generally removed. Several whole percentage points of the nation's gross domestic product ("GDP") are thus diverted wastefully to health care from other uses. The problem is not, as widely believed, the additional spending that results from the moral hazard inherent in any insurance scheme. Even though moral hazard operates with particular vengeance in health insurance, it can be managed to some extent, and its remaining costs may be entirely acceptable as a necessary cost of the valuable financial protection that insurance provides. ${ }^{84}$ Inefficiency occurs, however, as soon as government or the legal system barges in to preclude financing intermediaries from effectively managing care - that is, from taking administrative and other actions to limit the impact of moral hazard-or requires them to honor costly entitlements prescribed by law or professional standards rather than set forth in freely negotiated contracts. Indeed, the only moral hazard currently causing major inefficiency in the health care sector is the one that operates when employers, government, or the legal system write prescriptions for which consumers must pay. Aggregate welfare is less than it might be because the nation spends vast sums on services that no

82. Linda J. Blumberg, Who Pays for Employer-Sponsored Health Insurance?, HEALTH AFF., Nov./Dec. 1999, at 58. To be sure, employers can expect complaints if they reduce coverage or ask employees to pay more for it out-of-pocket. They may therefore prefer to impose some of the increasing cost of coverage on employees by holding down their take-home pay. Indeed, employers' need to maintain flexibility in passing on predictable increases in health premiums may explain much of their reluctance to shift to a fixed-contribution approach to providing health coverage. See Enthoven, supra note 55, at 41 ("[H]ealth insurance [is] usually the responsibility of human resources departments whose mission is to keep employees happy, not to rock the boat in ways that might make some unhappy.").

83. Pending federal patient protection legislation, see infra notes $115-121$ and accompanying text, may or may not include, if and when enacted, a provision extending its protections to federal employees, for whom Congress bears much of the cost of coverage. See Stephen Barr, Amendment to Patients' Rights Bill Riles Large Federal Health Plans, WASH. Post, July 15, 2001, at C2.

84. See Havighurst, Health CARE Choices, supra note 3, at 96-100 ("[S]ome overconsumption is an inevitable, and therefore tolerable, part of the cost of pooling financial risks."). 
one, neither consumers, nor health plans, nor government, has reckoned are actually worth what they actually cost.

Despite the importance of allocative efficiency as a desideratum in economic theory, most health economists seem untroubled by the apparent misallocation of excessive resources to health care in the United States. Perhaps this is because economists are generally taught that allocative inefficiency is mostly a technical problem, not a serious policy concern. ${ }^{86}$ Even monopoly, they learn, although causing too little productive capacity to be allocated to producing the monopolized good, results in surprisingly little "dead-weight loss" to the overall economy. ${ }^{87}$ One reason why economists might deprecate allocative efficiency as a policy goal is the so-called "problem of second-best," which suggests that, because there are so many other distortions in the economy, one more distortion is unlikely to make things appreciably worse. ${ }^{88}$ On this basis, and also because health care employs many people and yields a vast amount of consumer surplus (in the aggregate, if not at the margin), an economist might not view the over-allocation of resources to health care as a problem that should trouble policymakers. ${ }^{89}$

85. ENTHOVEN, supra note 3, at 11-30 (observing neglect of allocative efficiency in health policy). But see Korobkin, supra note 81, at 31 (seemingly opining that health care is being underproduced in the United States as a result of market failures that allow managed care plans to systematically economize at the expense of quality, justifying additional patient-protection regulation, but actually proving, at best, only that care might be underproduced in a totally free market without significant public subsidies).

86. Cf. Joel Waldfogel, The Deadweight Loss of Christmas, 83 AM. ECON. REV. 1328 (1993) (questioning the efficiency, though not the practice, of letting even well-intentioned people make consumption decisions for others).

87. See, e.g., F.M. SCHERER \& DAVID Ross, Industrial MARKET STRUCTURE AND ECONOMIC PERFORMANCE 667 (3d ed. 1990) ("[I]t appears that the dead-weight welfare loss attributable to monopolistic resource misallocation in the United States lies somewhere between 0.5 and 2 percent of gross national product.").

88. See, e.g., id. at 38 ("[O]ne might conclude that the whole question of allocative efficiency is so confused and uncertain, once second-best considerations are introduced, that policy-makers would be well advised to give up trying to achieve the best possible allocation of resources.").

89. For an illustration of the sanguine attitude of health economists toward the possibility that large increments of GDP are flowing into the provision of health care without anyone's consent and without any other assurance that substantial resources are not being wasted at the margin, see David M. Cutler \& Mark McClellan, Is Technological Change in Medicine Worth It?, HEALTH AFF., Sept.Oct. 2001, at 11. This study examines five new technologies and concludes (under the assumption drawn from "the literature" that additional healthy years of life are each worth $\$ 100,000)$ that "medical spending as a whole is clearly worth the cost." This conclusion amounts to nothing more than a finding that health care in general yields positive consumer surplus-hardly a surprise, since life-saving, when it occurs, has high value. On the other hand, it begs the much more important question of whether there is avoidable waste in some incremental spending. A particularly revealing feature of the CutlerMcClellan study is their valuation of neonatal care by valuing every year of healthy life that health care makes possible at $\$ 100,000$ each. Even discounting to present value, this method of making social judgments provides an irresistible warrant for extremely costly efforts to save even very low-birthweight newborns, even though rational individuals might prefer to save money for other uses by purchasing coverage that excludes this and other similarly heroic measures. In effect, government and the American legal system, aided and abetted by academic apologists, have stepped into the paternalistic shoes of earlier provider cartels to deny consumers the freedom to decide for themselves the extent to 
But even if allocative problems created by monopolistic overcharges in a few industries are trivial, it does not follow that the over-consumption induced by shielding consumers from most of the cost of both health care and health coverage is also of trivial concern. For one thing, second-best theorizingwhich suggests that eliminating monopoly in a given market will not necessarily improve resource allocation, because monopoly, taxes, and regulation cause many other goods and services also to be priced in excess of marginal costs and thus to be consumed at less than optimal rates-is a powerful reason for taking especially seriously, rather than discounting, the misallocative tendency of pricing health care below marginal cost and subsidizing it in ways unrelated to securing basic social justice. More generally, it is facially troublesome that health care spending represents one-seventh of GDP in the United States (even without providing fully for a huge segment of the population) while accounting for only a ninth of GDP or less in all other developed nations. ${ }^{90}$ Finally, looking beyond the matter of the efficiency of the overall economy, it appears that the cost of providing excessive health care in the United States falls disproportionately on the shoulders of lower- and middle-income premium payers, forcing them to allocate their own limited resources in ways they might deem adverse to their individual welfare. ${ }^{91}$ The remainder of this part of the article dramatizes the allocational problem in terms of this last observation.

From the foregoing, it is apparent that the moral hazard that matters most in health care results from the insulation of consumers qua consumers from the cost of their health coverage, enabling employers and the political/legal system

which their incomes should be spent on what they might consider to be marginally productive medical care.

90. See Gerard Anderson \& Peter S. Hussey, Comparing Health System Performance in OECD Countries, HeAlth AFF., May/June 2001, at 219, 227-28.

91. Although conventional thinking excuses taking significant choices away from people on the ground that they cannot evaluate health services, I know of no evidence clearly supporting the assumption that ordinary people will generally, in their ignorance, make choices that undervalue health care. The evidence most often cited is that consumers seem to choose health plans with price as the principal determinant, apparently ignoring the quality dimension. See Korobkin, supra note 81, at 56-59. But this tendency may signify only that, due to law and regulation narrowly prescribing the choices they are offered, today's consumers are operating at a margin where they see little risk of getting poorer quality than they are willing to pay for (and, consequently, feel safe in economizing as much as the system permits). To be sure, there is evidence that individuals consistently underestimate the health risks they face, for example, Neil Weinstein, Unrealistic Optimism About Susceptibility to Health Problems: Conclusions from a Community-wide Sample, 10 J. BEHAV. MED. 481 (1987), and it is therefore possible that ex ante choices about health coverage might reflect undue risk-taking. But everyone must anticipate a need for health services in the future, and at least some people, offered real health care choices and feeling uncertain and conflicted about the implicit trade-offs they are being asked to make, might be risk-averse, erring on the side of overspending rather than underspending. In any event, regulation will inevitably preclude many risky choices, and public subsidies can be designed to ensure that consumers will not economize in ways that expose them to undue risk. Thus, notwithstanding sophisticated analyses such as the extensive one offered by Korobkin, supra, note 81, there is no strong reason (other than analysts' assumption that everyone should choose the highest-quality care available, just as they would) to think that consumers cannot be trusted to choose for themselves among the options available. "Bounded rationality" is a fact of life, but it need not always be an excuse to turn consequential choices over to political decision-makers or judges who lack any incentive to ensure that consumers' money is spent as consumers themselves would rationally spend it. 
to take costly actions without having to account to employees/consumers/voters for their full costs. Unlike many other market failures warranting government interference in the economy, the moral hazard created by the hiding of health care costs is not inherent in the nature of health care or the marketplace. Instead, it is a consequence of policies consciously adopted by employers and government in subsidizing access to health care for employed individuals. For a variety of reasons, most employers eschew making fixed contributions for each employee to finance health benefits of their own choosing, even though that strategy would cause employees to make cost-conscious choices at the margin. ${ }^{92}$ On the other hand, government tax subsidies have no upper limit and thus dilute employers' sensitivity to the marginal price differences they face on their employees' behalf. The form of tax subsidies also allows employers to allocate substantial portions of their workers' incomes sub rosa to advance interests of their own-by artificially cultivating employee good will, for example, or attracting high-level employees.

The interesting question, to be examined below, is why subsidies for the purchase of health services continue to be provided in a form universally disapproved of by policy experts, both for regressivity and for distorting spending decisions. In other words, why do employers and government persist in following policies that exacerbate moral hazard not only in private consumption decisions but in public regulatory ones as well? This question prompts one to look for potent interest groups with a stake in systematically keeping health care costs hidden from the consumers/voters/employees who ultimately pay them. Obviously, most components of the health care industry itself prefer costs to be hidden and uncounted. But there may be others, too, with an interest in seeing that health care costs are borne by society in such a way that few occasions exist for comparing marginal costs and benefits, thus ensuring maximum funding for the health care enterprise.

\section{B. Who Gains? Who Loses?}

It is possible to illustrate graphically how consumers' ignorance about the incidence of health care costs, together with more widely recognized defects in the political process, induces the setting of especially inefficient regulatory and legal standards for health care and health plans. ${ }^{93}$ In Figure 1, a bell curve

92. See Enthoven, supra note 55.

93. For an earlier iteration of this model, see Havighurst, Backlash, supra note 10, at 401-08. As an exercise in "public-choice" theorizing, the model owes as much to concerns about the excesses of majoritarian politics as to cynicism based on the undue influence allegedly exercised by powerful, wellorganized special interests. Indeed, I believe I have identified an instance in which the twin banes of political democracy - the power of political majorities to exploit minorities and the ability of rentseeking special interests to victimize an ignorant or inattentive majority-operate in tandem to doubly bad effect. The story I tell can only disappoint scholars seeking to redeem democratic government's regulatory initiatives by arguing that voters and well-meaning politicians frequently transcend selfinterest and pursue the larger public interest even when theory predicts differently. See generally Symposium, Getting Beyond Cynicism: New Theories of the Regulatory State, 87 CORNELL L. REV. 267 (2002). Although the regulation of managed health care might appear to be an instance in which altru- 
represents the distribution of consumer demand for a hypothetical good or service that is available in both low-cost, low-quality versions (to the left) and high-cost, high-quality versions (to the right). To protect consumers against harms they might suffer from mistakenly purchasing poor quality, the government might intervene with regulation to preclude sellers from offering goods below a certain standard-say, point $o$ in Figure 1. In theory, a regulatory line drawn at point $o$ might be in the overall public interest even though it denies some individuals, mostly lower-income ones, their first choices and forces them to pay more than they would prefer to spend. ${ }^{94}$ Not only might such regulation spare the latter individuals the cost of injuries they might suffer from taking unrecognized or unwise risks, but other consumers, now having less reason to worry about buying very poor quality health care, could spend less time and other resources searching the market.

FIGURE 1:

REGULATING QUALITY

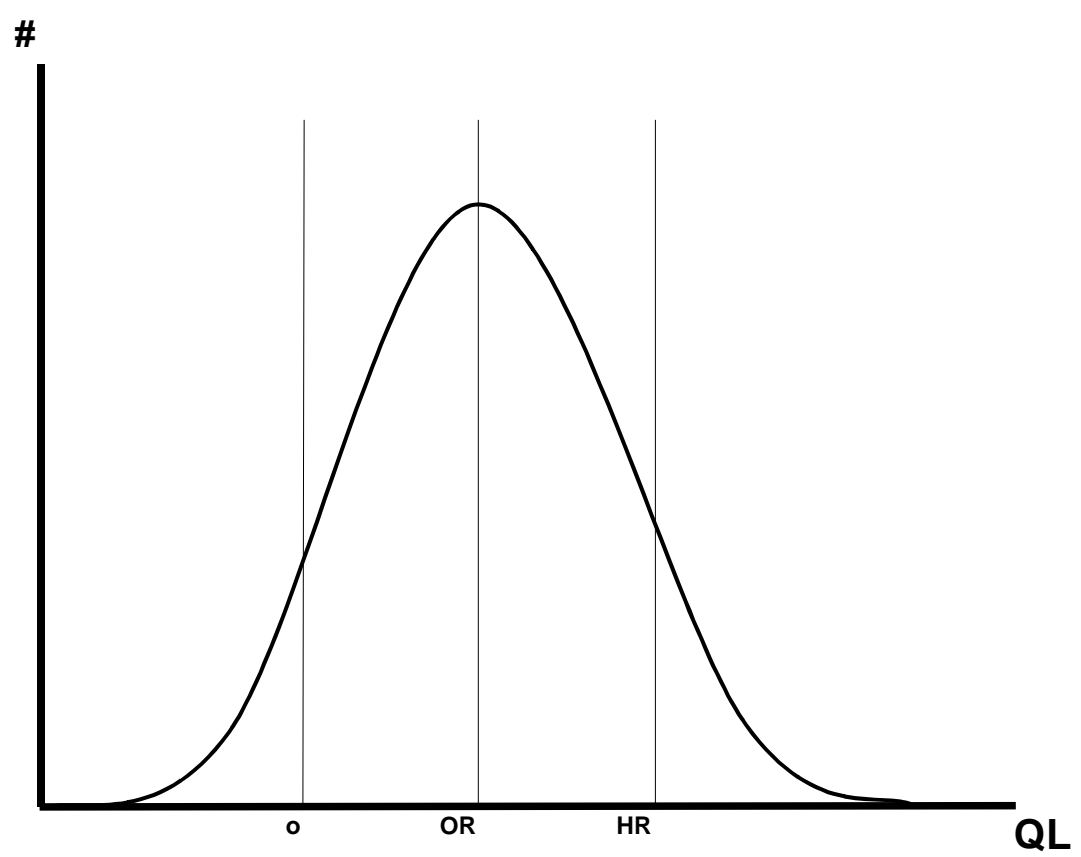

ism dominates, my analysis suggests that things have been rigged to dupe ordinary people into consistently voting against their true self-interest, thereby benefitting both industry interests and the upper middle class.

94. The result would be efficient in the "Kaldor-Hicks" sense, meaning that it is enough that gains to winners exceed losses to losers, even if the former do not have to compensate the latter. See Richard A. POSNER, ECONOMIC ANALYSIS OF LAW 13-15 (5th ed. 1998). That the costs of regulation fall mostly on lower-income persons does not affect the conclusion that regulation is efficient. 
But even though a degree of regulation might be justified under such a calculus, prescriptive regulation in a majoritarian world could easily impose costs on the low-income minority that substantially exceed any gains to the larger society. Particularly where the good or service being regulated potentially contributes to improved health or safety, ${ }^{95}$ one must consider the extent to which the higher prices prevailing under regulation cause some consumers to forgo purchasing the regulated good or service altogether. When inflated prices have this effect, substantial injuries could result, and should be counted among the costs of regulation. ${ }^{96}$ It is not enough that regulation raises the overall value of services actually provided; it must also not lower aggregate welfare by denying valuable services to even a small minority.

Unfortunately, the dynamics of the political market for consumer-protection regulation provide strong reasons to believe not only that standard-setting, command-and-control regulation systematically generates more social costs than benefits, but also that those costs are most likely to fall disproportionately on persons with lower incomes. The political majority, after all, would favor a regulatory standard set around point $O R$ (for "over-regulation") in Figure 1, at which point they would run fewer risks and save more search costs than at the optimal point $o$. Moreover, consumers/voters with preferences to the right of point $O R$ are the most aware, influential, and politically active members of the population, well-represented in the media and in policy-making circles. In addition, their interests in regulation guaranteeing higher quality would be congruent with the interests of many powerful industry groups, for whom high standards can eliminate low-cost competition and increase demand. ${ }^{97}$ Although other interest groups may sometimes provide countervailing political pressure against high regulatory standards, informal coalitions of upper-middle-class

95. Regulation is usually strictest in such cases because these are the areas in which the majority is most concerned with saving search costs and avoiding costly mistakes. See infra note 97 . To be sure, the concerns of consumers/voters that trigger regulatory responses by government are rarely expressed in terms of search costs or self-protection. Nevertheless, they are manifest in the snap judgments virtually everyone draws - in health care above all-about the desirability of high mandatory standards.

96. See, e.g., Sidney L. Carroll \& Robert J. Gaston, Occupational Restrictions and the Quality of Service Received, 47 SO. ECON. J. 959, 965 (1981) (setting minimum standards for licensing electricians found to increase accidental electrocutions; some citizens apparently elected to do their own electrical work, with tragic consequences).

97. Although professional influence is usually blamed for excesses in occupational licensing, economist Kenneth Arrow astutely observed as follows in a classic 1963 article on medical economics: The general uncertainty about the prospects of medical treatment is socially handled by rigid entry [i.e., physician licensing] requirements. These are designed to reduce the uncertainty in the mind of the consumer as to the quality of product insofar as this is possible. I think this explanation, which is perhaps the naive one, is much more tenable than any idea of a [medical] monopoly seeking to increase incomes. No doubt restriction on entry is desirable from the point of view of the existing physicians, but the public pressure needed to achieve the restric tion must come from deeper causes.

Arrow, supra note 81, at 966 (footnote omitted). In a recent symposium revisiting the Arrow article, not one of twenty-four separate comments focused on this perceptive explanation for the pervasiveness of prescriptive regulation in the health care sector. Symposium, Kenneth Arrow and the Changing Economics of Health Care, 26 J. HEALTH POL. POL’Y \& L. 823 (2001). 
voters and other special interests pressing for such standards will usually prevail.

Figure 1 also demonstrates why over-regulation is an especially (perhaps uniquely) severe problem in the health care sector. Occupational licensure excluding competent low-cost providers of health services from the market is just one example of the political system's insistence on high standards that protect the political majority against seemingly deficient quality while burdening lower-income consumers. ${ }^{98}$ The legal system's enforcement of high professional standards is another policy apparently supported by the political majority that excludes low-cost options from the market and forces many lowerincome persons either to pay for increments of quality or legal rights they may not want, or to go without health coverage altogether. ${ }^{99}$ In similar fashion, the recent political backlash against managed care shows how the upper-middleclass majority can obtain regulatory protection against what they perceive, accurately or not, to be poor-quality health coverage provided by managed care organizations. In this case, the affluent majority with preferences to the right of point $O R$ seek not merely to reduce the risk that they might unwittingly purchase low-quality health coverage, but also to limit what their employers can buy on their behalf. In all these matters, the political majority is strongly supported by the medical profession and other supply-side interests, as well as by sympathetic observers in the media and in the academy.

The political bias in favor of over-regulation is perhaps greater in the health care sector than elsewhere in the economy for at least three reasons. First, health care has particular salience in politics because of its symbolic value in establishing a politician's empathy with constituents' concerns. Second, the income-inelasticity of health care-that is, the tendency of people with higher

98. Carroll \& Gaston, supra note 96. State legislation also frequently requires health insurers to provide specific types of coverage. See, e.g., American Med. Sec., Inc. v. Bartlett, 111 F.3d 358, 362 (4th Cir. 1997) ("The State of Maryland regulates health insurance, requiring that health insurance policies afford at least 28 specified benefits."). Although these mandates are frequently attributed to lobbying by the providers of the covered services, most of them would also appeal especially to upper-middleclass consumers. See generally Gail A. Jensen, Regulating the Content of Health Plans, in AMERICAN HEALTH POLICY, supra note 45, at 167.

99. See supra notes 62-69 and accompanying text; see also Kenneth Arrow's famous 1963 article, which included the following observation:

[I]t would usually happen in a competitive market that many qualities will be offered on the market, at suitably varying prices, to appeal to different tastes and incomes. Both the licensing laws and the standards of medical-school training have limited the possibilities of alternative qualities of medical care.

Arrow, supra note 81, at 953. Although Arrow failed to appreciate how conservative tendencies in American law also contributed to the absence of product differentiation he observed, he rightly noted the force of regulatory controls and professional standards in denying people opportunities to choose a style of medical care appropriate to their circumstances. Writing well before the Medicare and Medicaid programs and tax subsidies for employer-purchased coverage poured enormous new public and private resources into health care and engulfed the industry in new waves of moral hazard, Arrow had little occasion for concern about the misallocation of resources that might result if society's usual mechanisms for making vital trade-offs are disabled. See supra text accompanying notes 85-90. 
incomes to spend higher percentages of their incomes on health services ${ }^{100}$ widens the usual preference gap between the upper-middle class and the rest of the population - that is, the distribution represented by the bell curve in Figure 1. Finally, both the likelihood and the regressivity of over-regulation are increased by the tendency of most consumers/voters to believe that insurers or their employers (rather than themselves) will pay the added costs of whatever quality, legal rights, or coverage they would like regulation to guarantee. ${ }^{101}$

When all these factors are combined, it seems certain that the political majority, in league with professional and other interests in the health care industry, will demand not just over-regulation of the health care sector (that is, a regulatory line drawn at point $O R$ in Figure 1), but hyper-regulation (for example, a line drawn somewhere in the vicinity of point $H R) .{ }^{102}$ The irony is that majoritarian politics, combined with the public's general unawareness of health care costs, allows the elite classes, including many self-proclaimed consumer representatives as well as organized professional groups, to design and maintain a system that meets their own particular needs but leaves less privileged citizens who are not qualified for publicly financed care with a Hobson's choice: either coverage for "Cadillac" care or no health coverage at all. Ruled as it is by and for dominant elites, the U.S. health care system imposes large, unfair, and unnecessary economic burdens on ordinary working people.

\section{Regressivity Compounded}

The impositions by the haves on the have-nots (or, more accurately, the have-lesses) do not necessarily stop with maintaining high regulatory and legal standards to protect affluent consumers against the risk that they will receive health care or health coverage they consider inferior. Even though all participants in a given health plan pay equivalent premiums and have the same nominal entitlements, individuals who are more demanding, knowledgeable,

100. Paul J. Feldstein, Health Care Economics 86-87 (5th ed. 1999).

101. Still another reason why upper-middle-class consumers might prefer standardization of health care and health coverage is that product differentiation interferes with price competition by adding dimensions to the product that make price shopping more difficult. Hammer \& Sage, supra note 15, at $275 \mathrm{nn} .119-20$. Thus, if health plans were not generally close substitutes for each other, an employer would find it harder to bargain over price with the plan it most desired. Likewise, consumers would have to pay more for access to higher-quality providers in a system featuring differentiated products, since plans striving for qualitative superiority would have to reward superior providers. (Currently, sophisticated consumers have an advantage in identifying and patronizing the best providers in their communities and can obtain their services at little or no additional cost to themselves.) See infra note 103.

102. Note that many of consumers' concerns about incurring excessive search costs and purchasing in ignorance could be addressed by public or private certification or accrediting programs that distinguish high-quality providers or plans from those of lesser quality but do not exclude the latter from the market. Upper-middle-class consumers would still prefer regulatory standardization of health care and health coverage, however, to preclude their employers from making choices with which they might disagree. Thus, they have an additional reason to want the government to foster health plans in which less sophisticated consumers also enroll, paying equivalent premiums without the same assurance of equivalent value. 
articulate, or assertive may regularly receive more or better services than other patients. $^{103}$ For example, physicians and other decision-makers may perceive that certain patients have especially high expectations concerning their health care, and may strive to accommodate those expectations while economizing on the care of others. On the other hand, some patients may be able to make more persuasive demands on their physicians because they are adept at using the Internet or are otherwise more knowledgeable about their health problems and treatment options. Others may simply be more skillful or persistent in questioning their doctors or seeking second opinions or may signal a litigious nature that providers or the plan might hope to appease by providing extra services. On top of all this, higher-income patients will also enjoy a disproportionate share of plan resources to whatever extent they are less deterred from consuming services by cost-sharing requirements. ${ }^{104}$ It seems inevitable that patients in higher socioeconomic classes will derive significantly greater value from their health plans than less affluent enrollees paying identical premiums. ${ }^{105}$ The regressive cross-subsidies implicit in American health care will therefore exceed even those inherent in its hyper-regulation.

To be sure, the inequities detailed above are ameliorated to the extent that employers structure their health benefits in ways that cause employees to segregate themselves in different health plans on the basis of risk aversion and ability to pay. As noted earlier, some employers now offer their employees

103. "Well-off and influential patients tend to link up with elite academic and private physicians, to sustain their relationships with these physicians, and to benefit from these physicians' sponsorship and advocacy in hospital and other institutional settings. Middle-class patients tend to access a lower level of sponsorship and advocacy...." M. Gregg Bloche, Race and Discretion in American Medicine, 1 Yale J. Health Pol'y L. \& Ethics 95, 108 (2001) (citing RAYMOND S. DufF \& August B. HOLLINSHED, SICKNESS AND SOCIETY (1968)).

104. Both theory and intuition suggest that cost sharing would have significantly greater effects on consumption of insured services by lower-income persons, thus adding to the regressiveness of insurance plans that ostensibly provide equal benefits for all enrollees. For empirical evidence, see JOSEPH NEWHOUSE ET AL., FREE FOR ALL: LESSONS FROM THE RAND HEALTH INSURANCE EXPERIMENT 339 (1993) ("Ambulatory services were more responsive to cost-sharing for the poor than for the wellto-do; the opposite was true for hospital services."). Although the RAND study found that, overall, "the percentage reduction in expenditure [attributable to cost sharing] did not differ strikingly by income group," id., a lower cap on out-of-pocket payments for the poor complicated the analysis, probably explaining the absence of deterrence with respect to inpatient care. See id. at 46-47. Most significantly for the purpose of identifying regressivity in employee health plans, the RAND data showed (despite the assertion that the overall effects of cost sharing did not differ by income group) that cost sharing had noticeably greater effects on middle-income persons than on either the higherincome group or the poor. Id. at 46 (table).

105. This point was driven home for me when, in the 1970s, my own employer merged its health plan for hourly-paid workers with its similar plan for faculty and staff. The result of this seemingly progressive move was in fact regressive, as the faculty's premiums fell significantly while the workers' premiums rose. If this phenomenon is pervasive (as I suggest it is), the U.S. health care system raises questions of social justice quite different from the ones usually asked. For suggestive evidence on nonracial socioeconomic disparities in health plans, see NEWHOUSE ET AL., supra note 104, at 46 (table) showing significantly higher predicted levels of use of medical services by higher-income persons than by middle-income persons); HMO Enrollees Experience Fewer Disparities than Other Insured Populations, 5 HeAlth CARE FIN. \& ORG. no. 2 (April 2002) (Findings Brief) (reporting unpublished findings by Kevin Fiscella et al. that HMOs reduce disparities based on education level but not income). 
multiple health plans with different prices so that their employee populations are somewhat stratified, with higher-income persons subscribing to costlier plans. Nevertheless, the overall regressivity of American health care seems clear. Not only is the fixed-contribution method of financing employee coverage still very far from being the norm, but (as earlier observed) the structure of tax subsidies makes it likely that any floor an employer setsincluding its contribution for a basic point-of-service plan-will be a relatively high one. In addition, hyper-regulation makes any qualitative differences between health plans relatively narrow ones. Because the entitlements on offer in the market for health coverage are all so similar at the core, consumers are unlikely to sort themselves out so that those who demand more and better services consistently pay the full incremental cost of the additional attention, or higher-quality services, they receive. Indeed, employees who are confident they can make any system work to their advantage may see no need to opt for a costlier plan.

Without objective evidence of consumers' true preferences with clear and accurate information, it would be impossible to estimate the magnitude of regressivity in a single large employment group, let alone to measure it in all privately financed health care. Either for this reason, or simply because analysts do not recognize the existence of inequity of the kind hypothesized here, no one appears to have measured the extent of the system's impositions on lower-income premium payers. On the other hand, many analysts have found racial disparities in the health care system. ${ }^{106}$ Although these disparities are generally attributed to racial bias, they may also be artifacts of patients' varying ability to "work the system," and of providers' discretion to prescribe services in accordance with their perceptions of patients' expectations rather than strictly according to objective medical need. ${ }^{107}$ Racial bias and stereotyping obviously merit study, but only political correctness (including a disinclination to recognize hypocrisy in the current regime) can fully account for the research community's focusing of so much attention on racial issues while neglecting the fundamental unfairnesses noted in this discussion-the burdens of which fall most heavily, ironically, on some of the very groups for whom solicitude is most fervently expressed. Similarly, experts widely study and deplore the inequity represented by the huge number of Americans without health insurance, while

106. For overviews of the findings on racial disparity, see InSTITUTE OF MEDICINE, UNEQUAL TREATMENT: CONFRONTING RACIAL AND ETHNiC DisPaRITIES IN HEALTH CARE (2002), available at http://www.nap.edu/books/030908365x/html/ (last visited Sep. 6, 2002); Bloche, supra note 103.

107. Some analysts have recognized that racial disparities may be ascribed in part to such factors. See, e.g., Robert A. Lowe et al., Effect of Ethnicity on Denial of Authorization for Emergency Department Care by Managed Care Gatekeepers, 8 ACAD. EMERGENCY MED. 259 (2001) (observing correlation between race and discrepancies in treatment authorization but suggesting as a possible explanation that black and Medicaid enrollees were less effective advocates for their own care); Stuart E. Sheifer et al., Race and Sex Differences in the Management of Coronary Artery Disease, 139 AM. HEART J. 848 (2000) (race-related disparities attributed to socioeconomic differences and black patients' resistance to cardiac procedures, as well as to racial bias). 
rarely attributing it to hyper-regulation maintained in the interest of dominant elites.

The most influential observers of the American health care systemincluding public officials, media commentators, academics, and denizens of wealthy foundations and other nongovernmental organizations-would probably argue that health care consumers do in fact have adequate chances to economize but have chosen not to do so. To these observers, health care of acceptable quality is inevitably expensive-it costs what it costs-and no one could rationally want anything less. The principal policy question, in their minds, is how to assist more people in paying for the high-quality care mandated by current regulatory requirements and to ensure its equitable distribution by anti-discrimination rules. An individual's personal support for progressive policies for the long run, however, does not justify supporting policies that are powerfully regressive in the short run, especially when, as Keynes said, "in the long run we are all dead." 108 There is, after all, ample reason to doubt that the political system will ever finance a system guaranteeing everyone care that meets the high standards these advocates support. ${ }^{109}$ Indeed, where other nations have more or less arranged their health care systems so that those who want more or better care than is suitable for the median citizen must pay more for it, the United States has structured things so that lower- and middle-income premium payers bear heavy burdens so that the elite classes can continue to enjoy the style of health care to which they are accustomed.

Few observers are troubled by the absence of explicit economizing opportunities in the health care marketplace. Indeed, far from deploring the lack of overt qualitative differences between health plans, most observers resist the suggestion that ordinary people should be free to make even fair bets against their developing a desire for especially expensive health services of uncertain efficacy. Although some experts argue that people want to be protected against making bets of this kind, ${ }^{110}$ what they may really be saying is that they themselves and people like them would prefer not to witness bets turning out badly for needy bettors. ${ }^{111}$ But assuaging guilt about life's unfairness

108. John MAYnARD KeYnes, A TraCt On MONETARy REFORM 80 (1923).

109. Because the cost of meeting high standards rises over time much faster than GDP increases, the political difficulty of providing universal access to care that meets such standards increases every year it is not done. The failure of the Clinton administration's health reforms may have been attributable to the high cost of trying to guarantee costly mainstream health care to everyone. See HAVIGHURST, HeAlth CARE CHOICES, supra note 3, at 79 ("[T] he political problems that the Clinton program encountered were traceable in large measure to its egalitarian thrust.").

110. See, e.g., Bruce C. Vladeck, The Market v. Regulation: The Case for Regulation, 59 MiLBANK Q. 209, 211 (1981). According to Vladeck, "Consumers have sought the kind of health insurance they have ... precisely because they don't wish to be forced to make rational trade-offs when they are confronted with medical care consumption decisions." Although it is true that people buy coverage to avoid difficult choices, Vladeck's statement begs the question whether people have in fact been offered choices requiring them to face the high marginal cost of the additional protection he says they demand.

111. To be sure, as Vladeck says, "As a society, we may be prepared to pay a substantial economic premium to insulate people from having to make such decisions." Id. at 212. But "society" has not in fact chosen to pay a "substantial economic premium" through a fair system of taxation and subsidies so 
cannot justify imposing heavy costs on those who would prefer to spend their moderate incomes on things other than generous health insurance. Indeed, an efficiency claim based on Kaldor-Hicks principles ${ }^{112}$ would seem to fail an elementary morality test if the majority that is offended when other people make economizing choices is demonstrably unwilling to provide public financing of the care they do not wish others to deny themselves. ${ }^{113}$ In any event, apparent egalitarianism and a commitment to high standards create a very convenient facade for hiding the regressive cross-subsidies that currently help to finance the United States' bloated health care system.

\section{Hyper-regulation: The New Wave}

Recent legislative and regulatory moves against managed care plans take on new significance in the context sketched in the foregoing discussion. Indeed, most of the latest actions and proposals may easily be seen as new reflections of the political dominance of upper-middle-class consumers desiring to see their employers prevented from choosing a health plan they might regard as inferior, and also desiring to see their health plans limited in their ability to resist the demands of patients with especially high expectations. Even modest "fixes" of minor problems perceived to exist in today's managed care plans need to be scrutinized to see if they further reduce plans' flexibility in addressing legitimate cost and quality problems or add to their administrative costs. Given the margin at which managed care regulation already operates (presumably represented by a line at, if not well to the right of, point $O R$ in Fig. 1), new regulatory restrictions on health plans are almost certainly poor substitutes for fundamental reforms-aimed, for example, at restoring some freedom of contract and making plans legally accountable when care provided under their auspices fails to meet contractual standards. ${ }^{114}$ Unfortunately, today's regulatory agenda appears to presume that the market reform strategy-of letting appropriately subsidized consumers and their agents make informed choices among freely competing health plans featuring different trade-offs between cost, quality, and financial protection-has failed a fair market test $\mathrm{t}^{115}$ and that more, not less, standardization is called for. Consumer-voters, well

that ordinary people can afford generous health coverage. Instead, it maintains a system that forces lower- and middle-income consumers to pay "substantial economic premium[s]" to health plans so that upper-middle-class consumers can be spared both the making of difficult choices themselves and the spectacle of lower-income individuals making them.

112. See supra note 94.

113. Conceivably, someone might claim that limited tax and other subsidies are provided specifically to compensate for marginal impositions on lower-income premium payers. However, that argument simply makes the system seem even more obviously rigged to accommodate concerns of the affluent minority, rather than designed to help people buy a merit good they truly need.

114. On the desirability of making plans presumptively vicariously liable for providers' torts (as a way of finally aligning plan and physician interests, inducing integration, increasing plans' stake in the quality of care, and generally legitimizing managed care itself), see supra notes 42-43 and accompanying text.

115. See Havighurst, supra note 1, at 1-14. 
insulated from cost concerns, have proved fertile ground for horror stories in the media and for politicians taking the populist line urged by medical interests.

A particularly vexing item on the agenda for reforming managed health care would increase the exposure of health plans to lawsuits for personal injuries when they arguably fail to live up to their obligations to cover to particular services. ${ }^{116}$ A powerful case can be made for giving consumers adequate legal redress against health plans that breach their contracts. On the other hand, legal rights can easily be abused-especially if, as appears to be the case, courts and juries are prejudiced against health plans, quick to exercise hindsight in difficult cases, and skeptical of contracts significantly limiting patient rights. ${ }^{117}$ If plans are fearful of unwarranted liability or even of the costs of defending defensible cases, they are likely to display unwarranted generosity, particularly toward anyone deemed likely to make legal trouble. Perhaps the most promising strategy would be to restore plan liability while explicitly authorizing plans to negotiate contractual limits on their legal exposure ${ }^{118}$ and to renegotiate their contracts to clarify that their obligations do not include underwriting everything professional standards might indicate. ${ }^{119}$

Another prominent element of the reform agenda is a movement to install so-called external review as the sole method for finally resolving close coverage issues. Under external review, health plans' own interpretations of their legal obligations to cover particular services would be only preliminary to appeals to professional experts lacking any connection to the plan and any commitment to carrying out its priorities in spending limited resources. Even if the external reviewer was charged with interpreting the plan's contract rather than with applying a purely professional standard, interpretations could easily differ in similar cases. Even more seriously, although much would depend on how the

116. See generally Wendy K. Mariner, Slouching Toward Managed Care Liability: Reflections on Doctrinal Boundaries, Paradigm Shifts, and Incremental Reform, 29 J.L., MED. \& ETHICs 253 (2001). The need for legislation results from ERISA. See supra note 72-74 and accompanying text.

117. On the environment health plans face when hauled before the courts, see Bob Van Voris, Pollsters Find No Love for HMOs, NAT'L L.J., Feb. 11, 2002, at 1 (fifty-three percent of respondents said that, as jurors, they would be "likely to vote for" a plaintiff against an HMO or hospital, while only eight percent would tend the other way). On the tendency of courts to disregard or liberally construe contractual limits on health coverage, see supra text accompanying notes 62-67.

118. It would be desirable, for example, to preserve the principle announced in Firestone Tire and Rubber Co. v. Bruch, 489 U.S. 101, 110-15 (1989), in which the Court held that, under ERISA, employers could confer substantial discretion on plan administrators interpreting coverage provisions of the plan, whose decisions would then be subject to review only for arbitrariness. Unfortunately, pending federal legislation looks in exactly the opposite direction. See, e.g., Bipartisan Patient Protection Act, S. 1052, H.R. 2563, § 104, 107th Cong., 1st Sess. (2001) (passed June 29 and Aug. 2, respectively) [hereinafter Bipartisan Patient Protection Act] (proposed new $\S 503 C(d)(3)(E)$ of ERISA would direct external reviewers to "consider the claim under review without deference to" the plan's decision and to "consider, but not be bound by," contractual provisions); see also Havinghurst, supra note 1 at 3 n.12 (describing how the legislation, although passed in 2001, is still waiting action by a joint conference committee).

119. The bargaining power of employers and any opportunity for consumers to choose between plans offering different legal rights should be sufficient to avoid the charge that contractual limits are a contract of adhesion. Cf. Madden v. Kaiser Found. Hosps., 552 P.2d 1178 (Cal. 1976) (holding that arbitration clause negotiated by employer was enforceable). 
requirement for external review was written and implemented, it could easily amount to a powerful reassertion of the professional paradigm, making professional standards even more binding on health plans than they currently are. ${ }^{120}$ Unfortunately, fear of new legal liability has apparently led the managed care industry to accept external review as a less objectionable alternative. Under external review, however, private health plans would lose control over coverage determinations and, with it, much of their raison d'être. ${ }^{121}$

Requiring external review of health plans' coverage decisions would rig the system still further in favor of the privileged minority of upper-middle-class consumers. An excellent illustration of this tendency is provided by the facts in a prominent ERISA case recently decided by the Supreme Court. In Rush Prudential HMO, Inc. v. Moran, ${ }^{122}$ the plaintiff, a resident of Illinois, sought treatment from the defendant HMO for a severe neurological problem in her shoulder. When the conventional therapies provided by her HMO doctors did not relieve her symptoms, she located an out-of-network surgeon in Virginia specializing in a unique kind of micro-reconstructive surgery, traveled to Virginia for examination, and became a candidate for the complicated operation. Although her HMO physician was willing to recommend this surgery, the plan's consultants (including several outside experts) did not approve it. Ms. Moran then underwent surgery in Virginia anyway, paid the cost $(\$ 94,841.27)$ herself, and sued the HMO to recover that amount. After lengthy appeals and negotiations, she eventually persuaded a court to order external review of her case by an independent physician pursuant to an Illinois statute. The reviewer, differing with the earlier experts, agreed that the more radical surgery, although not exactly what he would have recommended, was "medically necessary." The court of appeals eventually decided that the Illinois law was not preempted by ERISA and ordered the HMO to pay. ${ }^{123}$ Its ruling on the scope of ERISA preemption was affirmed by the Supreme Court. ${ }^{124}$

Putting aside the important legal question resolved in Moran, ${ }^{125}$ it is helpful for present purposes to consider the outcome achieved in the case under the

120. See, e.g., Bipartisan Patient Protection Act, supra note 118.

121. See generally Havighurst, supra note 45.

122. 122 S. Ct. 2151 (2002).

123. Prudential HMO Inc. v. Moran, 230 F. $3 d 959$ (7th Cir. 2000).

124. For other examples of the recent willingness of courts to reinterpret ERISA in ways that give wider effect to state law and state regulatory reforms, see Ky. Ass'n of Health Plans, Inc. v. Nichols, 227 F.3d 352 (6th Cir. 2000) (holding state "Any Willing Provider" law not preempted); Lazorko v. Pa. Hosp., 237 F.3d 242 (3d Cir.) (holding claim for injuries not preempted where managed care organization's refusal to rehospitalize patient could be treated as medical, not coverage, decision) cert. granted, 122 S. Ct. 2657 (2002); Pappas v. Asbel, 768 A.2d 1089 (Pa. 2001) (upholding personal-injury claim against HMO for alleged delay in treatment).

125. The Court held, 5-4, that ERISA's saving clause, see note 74 supra, allowed Illinois to impose the binding external review requirement on the HMO, despite Congress's intention to create a uniform federal regime governing employee benefit plans. The state law was deemed to pass several tests for establishing that a state law "regulates insurance" and is therefore saved from preemption by the saving clause. Madden, 122 S. Ct. at 2158-64. More controversially, the Court held that Illinois's requirement for binding external review did not amount to an impermissible alternative to ERISA's exclusive 
Illinois requirement for external review. Most people would probably applaud the result as a patient victory over a managed care plan interested only in its own bottom line. Indeed, it is easy to admire Ms. Moran's aggressiveness in seeking the best available treatment (perhaps finding the Virginia surgeon through a creative web search ${ }^{126}$ ) and her persistence in pursuing her legal rights. On reflection, however, it should be obvious that such aggressiveness and persistence should not necessarily be rewarded by making her HMO pay for the care she obtained. After all, other members of the HMO could not realistically have expected to get similar treatment for the same condition, yet they paid the same premiums she did. Indeed, the HMO seems to have performed a valuable service to its subscribers in conscientiously administering the pool of insurance premiums to ensure that one patient displaying special initiative would not get more out of the plan than other subscribers could reasonably expect to get under similar circumstances. ${ }^{127}$ The irony is that most observers of this case, both casual and expert, are likely to be persons with high expectations with respect to their own health care and thus to see the HMO's action as precisely what they expect regulation to prevent and Ms. Moran's presumed rights as precisely what they expect the law to vindicate. ${ }^{128}$

The Moran case and the Illinois regulatory regime it brought to bear on the defendant HMO illustrate how the political/legal system, with its essentially populist view of health care choices, tends to regulate the financing and delivery of health care to meet the expectations of upper-middle-class elites. External review essentially denies health plans any intermediary role in selecting treatments, limiting them to a passive role similar to that played by prerevolutionary health insurers, which dutifully paid for any care meeting professional standards as determined by professional authorities. Not only does such regulation drastically curtail opportunities for health plans to differentiate themselves, but a given plan could no longer hope to achieve consistency in administering its benefits. ${ }^{129}$ Moran also illustrates how professional judgments of outside reviewers are apt to vary widely in difficult cases. In addition, the Illinois scheme required the plan to submit to external review only when the

regime for enforcing civil obligations of employee benefit plans. Id. at 2164-71. In dissent, Justice Thomas argued that the Illinois statute did create remedies inconsistent with ERISA's exclusive enforcement mechanisms and persuasively objected to the majority's view that the Illinois-mandated review resembled a "second opinion" requirement more than a requirement for binding arbitration. Id. at 2171-78. For the majority, it was enough that an action to enforce the external reviewer's decision would still lie in federal court under ERISA's civil enforcement provisions, 29 U.S.C. § 1132(a) (2002).

126. The Virginia surgeon's website can be visited at http://jkterzis.com (last modified Sep. 17, 1998).

127. The district court in Moran had carefully reviewed the plan's handling of the claim, finding no abuse of discretion. See Prudential HMO v. Moran, No. 98-C-442, 1999 WL 417384 (N.D. Ill. June 15, 1999). The impression given by this review is that the plan went to great (and costly) lengths to make sure that its decision was right.

128. See, e.g., Ellen Goodman, A Case for Better Treatment, RALEIGH NEWs \& OBSERVER, Jan. 22, 2002, at 9A (syndicated columnist characterizes Moran case as "a timely, chilling reminder that patients haven't yet won protection from budgets and [HMO] bureaucrats").

129. See supra note 118. 
judgment of the patient's HMO doctor differed from that of the HMO's medical director and consultants. Obviously, not all primary care physicians would be equally knowledgeable about exotic alternatives such as the one Ms. Moran brought to her doctor's attention. Nor would they be equally willing to stand up to the plan for a particular patient, given the possible adverse consequences of doing so. ${ }^{130}$ In other cases, it would be up to the patient to initiate the challenge, which might not occur if the doctor had been co-opted sufficiently to withhold information about desirable alternatives or if the patient was temperamentally not inclined to fight.

In any event, the model of health care decision-making that is increasingly taking hold in the public mind and in regulatory policy is one that marginalizes the health plan as a responsible player. This model serves physicians and the provider community well, while also protecting those consumers/voters who especially want health care to be available to them without constraints. The political process has proved a powerful tool enabling special interests to shape the system to their liking. The costs of the system, borne in large measure by the mass of Americans who cannot easily afford such luxury, remain-by apparent design-hidden well enough that the day of reckoning is at least delayed.

\section{VII}

\section{MANAGED CARE IS DEAD！ LONG LiVE MANAGED CARE！}

Despite the apparent success of the counter-revolution against managed health care, it is hard to predict a long reign for a restored regime founded on such professional values as the "any-benefit" standard for medical and coverage decisions and the illegitimacy of intermediaries acting as consumer agents in procuring medical services. Indeed, rising health care costs are already a severe problem in the wake of the counter-revolution, leading to speculation that political conditions are ripening for a "perfect storm" that will drive health policy and the health care industry into uncharted waters. Although it would be foolish to predict where things will end up, this article concludes by exploring the possibility that managed care or something like it, perhaps bearing a less technocratic name, will re-emerge to restart and evenutally complete the American health care revolution, finally giving consumers some strategic control over their aggregate spending on health services. Without observing all the possibilities or all the political, legal, and practical pitfalls that lie in each

130. Note that the Illinois law irrevocably set up each treating doctor as an adversary of the patient's health plan, allowed to appeal over its head to professional authority. The same adversarial model of plan/provider relations, obviously destructive of any effort to integrate physicians and health care financing, see supra notes 5-7, 36-44 and accompanying text, is also embodied in the new legal right physicians increasingly enjoy to participate in plans that do not wish to retain them. See supra note 18 and accompanying text. These legal developments are among the most dramatic evidence of the remarkable success of the medical profession's counter-revolutionary move to reassert the professional paradigm of medical care, to remove economic trade-offs from consideration in clinical practice, and generally to roll back market reforms aimed at empowering consumers and their agents. 
possible path, the following paragraphs suggest what health plans might do, individually and collectively, to establish themselves as legitimate, trustworthy executors of consumer preferences. Specifically, I suggest that health plans might finally begin to differentiate themselves in ways that enable them to serve the economic interests, as well as the health care needs, of different subsets of the consuming public. Only a responsive market offering consumers real choices can ameliorate the regressivity and misallocative tendencies that this article has observed in American health care.

The discussion here focuses only on what private actors, not government, might now do to revive the lost revolutionary cause. It is necessary to hope, of course, that the political/legal system, which is congenitally uncomfortable with any arrangement that contemplates denying a desired health service to anyone except on the ground of its sheer worthlessness, will not finally foreclose all remaining opportunities for private innovation addressing the dilemma of health care costs. ${ }^{131}$ But, with health care costs spiraling out of control, government might at least look the other way as employers and health plans begin to explore new ways to harness consumer cost-consciousness as a counterweight to the system's propensity to overspend. For their part, employers are already shifting greater shares of the cost burden directly to employees and contemplating reliance on fixing their contributions, rather than redesigning their benefits, to control their costs. Although some recent moves by employers and health plans seem shortsighted ${ }^{132}$ competitive pressures and intensifying cost concerns may yet induce health plans to think outside the box, beyond the professional paradigm and individual cost sharing.

Fortunately for the scenario-cum-agenda sketched here, regulation and the legal system do not appear to pose insurmountable obstacles to offering consumers an appreciable range of health care choices. Indeed, most of the failings of the managed care movement are attributable less to substantive law and regulation than to health plans' own conservatism and the nature of their contracts with subscribers. Thus, the "medical necessity" criterion appears in virtually all contracts for health coverage, not because that criterion was generally mandated by law, but because health plans voluntarily embraced a powerful industry convention. In the Moran case, the Supreme Court observed

131. On the potential destructiveness of federal patient protection legislation pending in 2002 , see note 133 infra; see also Havighurst, supra note 1, at $4 \mathrm{n} .12$ (speculating that the federal bill is unlikely to leave the joint conference committee).

132. One new development is increasingly complex and burdensome cost-sharing arrangements (some featuring different co-payments for as many as three tiers of provider or product choices). Another significant trend among employers is to make so-called "defined contributions" to individual accounts that employees can use to purchase health care directly, with protection against very large expenses supplied by catastrophic coverage. These various arrangements either obviate activist roles for managed care plans or bypass such plans altogether, strongly implying that they are no longer capable of adding significant value. Thus, the new strategies presume that individual consumers are good enough decision makers with respect to health care not to need assistance from intermediaries of any kind. For convincing reasons why such arrangements are unlikely to slow cost trends attributable to uncontrolled moral hazard, see Victor Fuchs, What's Ahead for Health Insurance in the United States?, 346 NEW ENG. J. MED. 1822 (2002) (also regretting on social grounds the higher burdens the new arrangements inevitably impose on older or sicker insureds). 
that the HMO defendant "chose[] to guarantee medically necessary services to plan participants" and that "insurance contracts do not have to contain such guarantees, and not all do." ${ }^{\prime 33}$ Moreover, the Illinois external review requirement at issue in Moran applied only to disputes over medical necessity, apparently leaving other coverage limits to be administered by plan personnel, subject to ordinary judicial review in suits for breach of contract. The situation in Illinois following Moran thus invites health plans to specify criteria for coverage that do not incorporate professional standards as such, and there appears to be similar room in other states for defining coverage in unconventional terms. ${ }^{134}$ Health plans may therefore have an opportunity to break their attachment to medical necessity and professional standardsinefficient criteria in any event-and to develop various new ways of stating their obligations to subscribers. Although the legal system has been unreceptive to contractual limits on coverage in the past, a new crisis in health care spending might induce courts, legislatures, and regulators finally to respect well-crafted efforts to respond to consumer cost concerns. Also, while fear of adverse selection has heretofore inhibited substantial qualitative differentiation among health plans, contractual limitations can do much to prevent those initially choosing cheaper coverage from upgrading when a medical need appears. ${ }^{135}$

To be sure, any general criterion for coverage other than medical necessity would be subject to the charge of vagueness and ambiguity and difficult to apply in practice. These difficulties could be largely overcome, however, if the managed care industry undertook collectively to specify standard contract language defining three or four "tiers" of coverage, representing graduated levels of generosity, and gave consumers other guidance concerning the relative generosity of various plans. ${ }^{136}$ If consumers were better

133. 122 S. Ct. at 2167 n.10.

134. Even if other states seem to mandate medical necessity as a standard in all health plan contracts or to require external review of all coverage decisions (not just those based on medical necessity), there may be substantial room for escaping professional standards by contract. Thus, a contract may adopt the medical necessity criterion but define it in a way that makes the actual test a contractual rather than a professional one. Likewise, a contract might expressly bind external reviewers to apply standards drawn from the contract, not from professional sources. But see Bipartisan Patient Protection Act, supra note 117 (proposed new $\S 503 \mathrm{C}(\mathrm{d})(2)$ of ERISA would mandate external review of any coverage decision based on "medical necessity or appropriateness" or otherwise "based on grounds that require an evaluation of the medical facts by a health care professional"; proposed new $\S 503 \mathrm{C}(\mathrm{d})(3)(\mathrm{B})$, (C) would free reviewers from honoring contractual limits unless the applicable exclusion is categorically or numerically "exact"). $C f$. HAVIGHURST, HEALTH CARE CHOICES, supra note 3, at 139-43 (observing the inefficiency, due to inevitable arbitrariness, of "exact" categorical exclusions, fixed dollar or service limits, and cost-sharing requirements). Rather obviously, passage by Congress of the Bipartisan Patient Protection Act in its current form would virtually eliminate contractual limits on coverage as reliable instruments by which health plans might curb spending on cost/benefit grounds.

135. See supra note 53 and accompanying text.

136. A similar strategy for assisting consumers choosing complex insurance products has been employed by the federal government with respect to so-called "Medigap" coverage. 42 U.S.C.A. $\S$ 1395ss (2000), 42 C.F.R. $\S 403.200$ (2000) (differentiating ten different tiers or varieties of coverage supplementing Medicare benefits). For sample definitions, see HAVIGHURST, HEALTH CARE 
informed in this way, it should be possible to enforce their ex ante choices even if regrets arose ex post. Industry efforts to standardize coverage criteria would also enhance consistency and predictability in contract administration, obviating many disputes. Under a new generation of contracts, physician reviewers would serve only as technical experts in applying plan-specific criteria, not as arbiters of treatment under professional standards.

Obviously, contract drafters would want to leave as few coverage issues as possible to be resolved under an inevitably uncertain general standard, even one that had acquired some conventional meaning. To add desirable concreteness to differentiated health care contracts, ethicist Haavi Morreim has recently endorsed "guidelines-based contracting." clinical practice guidelines and protocols by reference in their contracts with subscribers, health plans could minimize arbitrariness and inconsistency of the kind suspected in coverage determinations today. Ideally, guideline producers would expressly tailor their products to correspond to the different general coverage criteria in use in the industry. Again, industry collective action could be helpful in clarifying and validating the options being offered. Private (or public) certification of alternative guidelines might also enhance public confidence in plan policies.

A health plan might also improve its reputation for fairness if, in cases where its contract did not cover a costly procedure, it was willing to indemnify the patient in an amount equivalent to the cost of the usual treatment. ${ }^{138}$ Certainly, the equitable position of the HMO in the Moran case would have been stronger if it had not conditioned its willingness to pay anything toward Ms. Moran's care on her acceptance of its standard therapy. It is not known how many of today's health plans provide cash indemnities for patients who elect treatments costlier than those the plan covers. Most plans, however, seem to approach coverage decisions on the premise that they are implementing objective professional standards and are under no obligation to subsidize deviations from them. This pretense of omniscience in applying professional standards is a major source of managed care's public and provider relations problems. If it were dropped in favor of pure contractual standards, a plan could convincingly claim that it was doing nothing more than administering a limited pool of resources on contractual terms, thus averting criticism (and possible legal liability) for "practicing medicine."

Health plans could improve their contracts and their service to subscribers in other ways as well. A heroic but vital step would be acceptance,

CHOICES, supra note 3, at 192-94 (suggesting contract language defining six possible alternative criteria for coverage, in ascending order of liberality).

137. HaAvi Morreim, Making Health CARe Accountable 126-36 (2000). See also HAVIGHURST, HEALTH CARE CHOICES, supra note 3, at 222-64 (elaborating the case for incorporating selected guidelines in health care contracts, with examples); Havighurst, supra note 24, at 796-804 (observing potential of practice guidelines for overcoming contract failure in health care).

138. For other ways in which a health plan might clarify that it has not set itself up as the final arbiter of treatment, see HAVIGHURST, HEALTH CARE CHOICES, supra note 3, at 140, 189 (suggesting high-e.g., $50 \%$ - cost sharing for nonstandard care and/or plan loans to patients desiring such care). 
by contract or by statute, of substantial legal responsibility both for their own errors in determining coverage and for the torts of their chosen providers. If a plan were to accept such liabilities by contract rather than having them imposed by substantive law, it would be able to set terms, procedures, and limits striking a proper balance between accountability and cost. Regrettably, the managed care industry has been so fearful of liability exposure that, rather than defending its members' freedom to innovate in the interest of consumers, it has taken the opposite tack of seeking the cover of regulation and professional standards for virtually everything its members do. To be sure, the industry's reluctance to accept legal accountability is attributable in large measure to the legal system's inability to protect health plans from both unwarranted liability and the high cost of defending unwarranted lawsuits. But reasonable exposure to liability is essential to deter firms from abusing their competitive freedom, which must be preserved if they are to serve consumers well. Indeed, if private health plans gain protection from litigation by surrendering their freedom to offer consumers meaningful alternatives, there is no obvious reason why they should not be replaced by a government-run financing system. ${ }^{139}$ The managed care industry's reluctance to accept legal responsibility for its members' performance is a major reason why the health care revolution failed ${ }^{140}$ and why it may be impossible to restart it. By the same token, nothing could do more than legal accountability to help health plans regain the trust they need to perform the sensitive tasks assigned to them in the health care revolution.

Note that there are two kinds of legal liability to which health plans must be exposed on reasonable terms if their legitimacy as participants in health care decisions is to be restored. First, plans must accept some responsibility for injuries caused when they breach their contracts to provide coverage. Fortunately, the daunting risk of plan liability for coverage decisions that a court or jury might deem erroneous in retrospect would be lessened if a plan had embraced other elements of the contract-based strategy outlined here. Thus, if contracts effectively conveyed the limited extent of the plans commitment, perhaps by incorporating specific guidelines, there would be fewer disputable decisions. Moreover, if it were clear that the plan makes only coverage, not treatment, decisions, plaintiffs would face substantial causation issues if the patient failed to appeal the plan's original decision or had the option of spending other money to obtain the desired treatment. Arbitration clauses and provisions setting reasonable limits on liability would also help plans stand behind their coverage determinations.

Presumptive vicarious legal liability for physician malpractice and for other provider torts is an equally important key to legitimizing private financing intermediaries in health care. ${ }^{141}$ As noted earlier, profit-oriented health plans

139. See Havinghurst, supra note 45. See also Fuchs, supra note 131, at 1823-24 (predicting eventual program of national health insurance in part because "employment-based health insurance has high administrative costs but provides no advantages to society as a whole").

140. See supra notes $41-44,71-78$ and accompanying text.

141. See generally Havighurst, supra note 42 (proposing vicarious liability as the default rule, subject 
were allowed to become responsible de facto for controlling the cost of care while remaining generally immune from any legal responsibility for its quality. This situation, which is now being ameliorated by curbing plans' ability to control costs, was so illogical as to induce wonder how the political/legal system ever allowed it to develop. In any event, it is within the power of individual health plans to assume such liability voluntarily, thereby perhaps re-legitimizing their efforts to resist the effects of moral hazard. ${ }^{142}$ The benefits of so doing would include better alignment of the plan's interests with providers' concerns about patient outcomes and quality, thus lessening plan/provider conflict and facilitating more plan/provider integration than has generally been seen in the health care revolution. Vicarious liability would also induce plans to take effective steps to improve the quality of care and to ensure that their physicians honor their professional obligations to patients. ${ }^{143}$

For managed care to recover its legitimacy, health plans not only must offer innovative products to consumers, but must also level with consumers about precisely what they are selling, stressing its limitations as well as its benefits. To clarify what is being sold, for example, plan literature might give consumers examples of the kinds of coverage limits the plan imposes, showing how controlling guidelines operate to limit the plan's obligation in particular cases where good alternatives are available. Such disclosures not only would help to prepare enrollees for possible disappointments down the road, but would also make the reasonableness of plan policies more apparent. Plan materials should also explain the trade-offs that have been made, showing how the consumer benefits in lower premiums from the restrictions imposed on all enrollees. ${ }^{144}$ Such candor would give consumers not only a clear idea that they were purchasing something less than Cadillac-quality coverage, but also an understanding of why it might make sense for them to do so. With consumers aware to this extent of the limits of their entitlements, it would be reasonable to

to a limited right of plans to delegate legal responsibility to subcontracting provider organizations).

142. Many physicians are currently facing burdensome new increases in the cost of their malpractice coverage and may be receptive to new proposals to shift their liability to other shoulders.

143. See Havighurst, supra note 42, at 18-22 (arguing that vicarious liability would strengthen incentives to maintain and improve quality and would promote, not undermine, physicians' professionalism). To see how plan/provider tensions would be reduced and professionalism reinforced, consider that a plan facing vicarious liability for injuries caused by a physician's failure to tell a patient all his treatment options would have an additional reason (besides ensuring that its coverage decisions do not necessarily determine actual treatment) to encourage physicians to disclose such alternatives-something plans have been strongly criticized by physicians for discouraging.

144. Thus, a plan contract might include a provision like the following one:

Your Reasons for Accepting Limitations on Your Legal Rights. You acknowledge that you have agreed to the foregoing limitations on your entitlements under the Plan and to the foregoing rules governing the interpretation and enforcement of your legal rights under the Plan-

(a) in order to ensure that the premiums collected from you and other Plan subscribers are disbursed according to agreed-upon rules and

(b) in consideration of (1) the acceptance by other Plan subscribers of the same limitations and rules and (2) the lower Plan premiums that these limitations and rules make possible.

Adapted from Havighurst, HeAlth CARE CHOICES, supra note 3, at 188. 
expect both individual patients and the courts to accept the situation whenever the coverage purchased proved less generous than they would wish.

However promising the foregoing scenario may seem, the prospects for re-energizing health plans as revolutionary agents are, unfortunately, greatly diminished by a number of circumstances. An individual health plan embarking on such radical innovations would clearly face prohibitive obstacles, including providers' hostility, regulators' skepticism, litigation risks, and the high cost of marketing new products to an entitlement-oriented public. Indeed, the risks and costs facing any first mover would be so great that meaningful change probably cannot occur unless at least a major segment of the industry were willing to redefine its mission and to take substantial collective actions in aid of the cause, such as promoting new criteria for coverage, new guidelines implementing those criteria, and accrediting and other measures designed to validate new products. Such revolutionary collective actions would be taken only if industry participants became deeply convinced that their survival in the business of financing health care required radical measures. It is doubtful that either individual managed care firms or the industry as a whole will ever perceive either the opportunity or a need to reinvent themselves in the ways contemplated here.

\section{VIII}

\section{CONCLUSION}

As this article has shown, Managed Care I proved itself a poor public servant and was appropriately deposed in the counter-revolution it inspired. Managed Care II apparently believes that, by cultivating a more benevolent image than its predecessor, it will be able to hang onto power and ride out any "perfect storm" that may be brewing and that its members can survive (despite their relatively high costs) as private functionaries in a market increasingly dominated and controlled by government. Perhaps the industry is right that it faces no emergent need finally to pick up the revolutionary banner and carry forward the people's cause. (HMOs' share prices have risen, against the trend, so far in 2002.) In any event, it has yet to produce statesmen with the vision and leadership that would be needed to restart the health care revolution in the name of exploited consumers. To be sure, heroes may yet arise to revive the revolutionary cause. But most observers will probably conclude that, despite the forceful logic supporting the neo-revolutionary agenda envisioned here (and the vision of the original proponents of a market-oriented health care system), it is unrealistic even to hope that consumers will eventually be empowered to resist contributing their hard-earned dollars to support the American health care enterprise-maintained as it is by, and for, a loose but powerful political coalition comprising both a vast industry and the most affluent consumers of its services. In the probable correctness of this pessimistic conclusion lie some 
powerful lessons about the nature and limitations of American culture and American institutions. 